\title{
Dergiabant
}

Cilt/Volume: 9, Sayı/Issue: 1

(Mayıs/May 2021)

\section{Arap Dilinde İsm-i Fâil ile Fiil Arasındaki Kullanım İncelikleri: Kur'an-ı Kerim'den Örnekler Çerçevesinde}

\section{Usage Variances between Ism al-fācil and Verb in Arabic language: Within the Framework of Examples from the Qur'ān}

\author{
Sedat Sağdıç \\ Dr. Öğr. Üyesi, Bolu Abant İzzet Baysal Üniversitesi, İlahiyat Fakültesi, \\ Arap Dili ve Belâgatı Anabilim Dalı \\ Asst. Prof. Dr., Bolu Abant Izzet Baysal University, Faculty of Theology, \\ Department of Arabic Language and Rhetoric \\ Bolu/Turkey \\ sedatsagdic@gmail.com \\ orcid.org/0000-0003-3008-0841 \\ $\underline{\text { Makale Bilgisi }} \underline{\text { Article Information }}$
}

Makale Türü: Araştırma Makalesi

Geliş Tarihi: 25 Şubat 2021

Kabul Tarihi: 6 Mayıs 2021

Yayın Tarihi: 30 Mayıs 2021

Yayın Sezonu: Bahar
Article Type: Research Article

Date Received: 25 February 2021

Date Accepted: 6 May 2021

Date Published: 30 May 2021

Publication Season: Spring

https://doi.org/10.33931/abuifd.886850

Intihal/Plagiarism

Bu makale özel bir yazılımla taranmış ve intihal tespit edilmemiştir.

This article has been scanned by a special software and no plagiarism detected.

Atıf/Cite as

Sağdıç, Sedat. "Arap Dilinde İsm-i Fâil ile Fiil Arasındaki Kullanım İncelikleri: Kur’an-ı Kerim'den Örnekler Çerçevesinde”. Dergiabant 9/1 (Mayıs 2021), 403-426. https://doi.org/10.33931/abuifd.886850

Copyright $\odot$ Published by Bolu Abant Izzet Baysal University Faculty of Theology, Bolu, 14030 Turkey. All rights reserved. https://dergipark.org.tr/tr/pub/dergiabant 


\title{
Arap Dilinde İsm-i Fâil ile Fiil Arasındaki Kullanım İncelikleri: Kur'an-ı Kerim'den Örnekler Çerçevesinde
}

\begin{abstract}
Öz
Dilbilimciler hiçbir farklı siganın hatta kelimenin tamamen aynı anlamda kullanılamayacağını söylemişlerdir. Bu genel kural tabii ki çok zengin bir dil olan Arapça için de geçerlidir. Arap dilinde ism-i fâil ve fiil sigası kullanım açısından benzerlik göstermektedir. Bununla beraber tamamen aynı manada kullanıldıklarını söylemek çok zor dahası imkânsızdır. Her iki kullanım arasında nüanslar vardır. Zaten gerek klasik gerekse modern Arap dili gramer kaynaklarında bu farklara detaylıca temas edilmiştir. Kur'an-ı Kerim Arap dilinin zirve kitabıdır. Dolayısıyla Arap dilinde mevcut olan kullanım inceliklerinin hepsini içerisinde barındırmaktadır. Bu husus Kur'an-ı Kerim'in dil yönünden mucize oluşunun da kanıtlarından biridir. Ele alınan konu bağlamında değerlendirilecek olursa Kur'an-ı Kerim'in kimi yerde ism-i fâil, kimi yerde fiil kullandığı dikkat çekmektedir. Bunlar yüzeysel olarak değerlendirildiğinde her iki kullanımın aynı anlama geldiği şeklinde bir sonuca varılabilir; fakat iyi tetkik edildiğinde aralarında bazı nüansların olduğu görülecektir. Nitekim Arap dili belâgatı âlimleri ve müfessirler bu hususlardan hareketle Kur'an'ın tamamını dil ve belâgat yönünden incelemişler.
\end{abstract}

Anahtar kelimeler: Arap Dili, İsm-i Fâil, Fiil, Kur'an, Tahlil.

\section{Usage Variances between Ism al-fā'il and Verb in Arabic language: Within the Framework of Examples from the Qur'ān}

\begin{abstract}
Linguists have said that no different mode or even the word can be used in exactly the same sense. This general rule of course also applies to Arabic, which is a very rich language. In the Arabic language, ism al-fā'il and verb șīgha are similar in terms of usage. However, it is very difficult or even impossible to say that they are used in exactly the same sense. There are nuances between both uses. These differences have already been discussed upon in both classical and modern Arabic grammar sources. The Qur'ān is the top book of the Arabic language. Therefore, it contains all the subtleties of use that available in the Arabic language. This issue is one of the proofs of the Qur'ān 's being a miracle in terms of language. In the context of our subject, the Qur'ān uses ism al-fā'il in some places and verbs in others. When these are evaluated superficially, it can be concluded that both uses have the same meaning, but when examined thoroughly, it will be seen that there are nuances among them. As a matter of fact, Arabic language rhetoric scholars and commentators have examined the entire Qur'ān in terms of language and rhetoric, based on these issues.
\end{abstract}

Keywords: Arabic Language, Ism al-fā'il, Verb, Qur’ān, Analysis.

\section{Giriş}

Arap dilinde isim ile fiilin benzer noktaları olduğu gibi farklı tarafları da vardır. Buna bağlı olarak bir isim türü olan ism-i fâilin de fiil ile ortak ve farklı hususiyetlerinin olması gayet tabidir.

İsm-i fâil ve fiil ile ilgili gerek makale, gerekse tez düzeyinde çok sayıda çalışma yapılmıştır. Fakat buna rağmen aralarındaki kullanım inceliklerini müstakil olarak ele alan çalışmaya rastlamadık. Her ne kadar bazılarında aralarındaki nüanslara değinilse de bunlar çok az ve konunun anlaşılmasına katkısı yetersizdir. $\mathrm{Bu}$ sebeple böyle bir konuyu araștırmak istedik. Ayrıca ism-i fâil ile fiilin benzer yönlerini 
dikkate almamaktan kaynaklanan meal problemleriyle ilgili bir kongrede sunduğumuz bildiri, bizi farklı yönlerini de çalışmaya sevk etti. Bu farkları gramer kitaplarının yanı sıra ayetler üzerinden de göstermek istememizin sebebi Kur'an'ın Arap dilinin zirve kitabı olması hasebiyledir. Dolayısıyla bütün bu ince anlam farklarını en güzel Kur'an'da bulacağımızı düşündük. Bu noktada müracaat ettiğimiz tefsir kaynaklarının dilbilimsel, en azından dil ağırlıklı olmasına dikkat ettik. Zira ayetlere temel yaklaşımımız tefsir ilmi açısından değil, tamamen dil eksenli oldu.

Bu farkların tespit edilip netleştirilmesinde "hudûs", "teceddüt", "sübût", "devam" ve "istimrâr" gibi kavramlar önemli rol oynamaktadır. Zira bu kavramlardaki kapalılıklar kimi zaman birbirleriyle karıștırılmalarına sebebiyet vermektedir. Her ne kadar bazı dil, belagat ve tefsir kitaplarında bu kavramlar açıklansa da bunların dağınık ve farklı eserlerde olması hasebiyle istifadesinin güç olduğunu gördük. $\mathrm{Bu}$ sebeple bu kavramların anlamlarını ve birbirleriyle ilgilerini açıkladık.

Bu çalışma giriş ve iki bölümden oluşmaktadır. Birinci bölümde isim ve fiil hakkında genel bilgiler verilip aralarındaki farklara temas edilecek. Ardından ism-i fâilin Arap dilindeki konumundan bahsedip fiille aralarındaki farklar ortaya konulacak.

Çalışmada çok sayıda dil ve belâgat kaynağından yararlanıldı. Klasik kaynaklardan İbn Serrâc'ın (öl. 316/929) el-Usûl fínn-nahv'i ile Modern dönem Arap dilcilerinden Mustafa Galâyînî'nin (öl. 1944) Camiü'd-durûsi'l- 'Arabiyye adlı kitabı ön plana çıkan eserlerdi. "Hudûs", "teceddüt", "sübût", "devam" ve "istimrâr" gibi kavramları netleștirmede Teftâzânî'nin (öl. 792/1390) Muhtasarü'l-me'ânî'si ile özellikle de bunun haşiyesi olan Desûki'nin (öl. 1230/1815) Hâşiye alâ şerhi't-Telhîs'i önemli rol oynadı. İsmin sübût manasını net bir biçimde ortaya koyan Abdülkâhir elCürcânînnin (öl. 471/1078-79) Delẩilü'l-i'câz adlı orijinal eseri önemli bașka bir kaynaktı.

İkinci bölümde ism-i fâil ile fiil arasındaki bu farklar dokuz ayetle Kur'an üzerinden gösterilmeye çalışılacak. Örnekler hem ism-i fâil hem de fiilin aynı bağlamda geçtiği ayetlerden seçilecek. Bu ayetler mushaftaki sırasına göre verilecek.

Kur'an-ı Kerim'deki ism-i fâil ile fiil arasındaki kullanım inceliklerini ortaya koymak için dil yönü ağır basan on beşi aşkın tefsir kaynağından istifade edildi. Bunlar arasında Ebûssuûd'un (öl. 982/1574) Tefsîrü Ebî’s-Su'ûd'u, Âlûsî’nin (öl. 1270/1854) Rûhu'l-me'ânî'si, Râzî'nin (öl. 606/1210) Mefâtîhü'l-gayb'ı, İbn Âșûr'un (öl.1973) Tefsîrü't-tahrîr ve't-tenvîr'i, Ebû Hayyân'ın (öl. 745/1344) Tefsîrü'l-bahri'l-muhît'i ve İbn Arafe'nin (öl. 803/1401) Tefsîrü İbn 'Arafe'sini özellikle zikretmekte fayda mülahaza edilmiştir.

Ayrıca Arap dili ve belâgatı alanındaki uzmanlığının yanı sıra Kur'an'ı anlama ve yorumlama çabalarıyla ön plana çıkan yaşayan âlimlerden Fâdıl Sâlih Sâmerrâî'nin bu alandaki birikimi araştırmada yönlendirici bir etkisi olmuştur. Zira o, hemen hemen bütün eserlerinde bu tür konuları ele almakta, dikkat çekici yorumlarda bulunmaktadır. 


\section{1. İsim, Fiil ve İsm-i Fâil'in Genel Kavramsal Çerçevesi}

\section{1. İsim ve Fiil}

İsim خالدُ , فرسٌ ,عصفورٌ ,دارٌ örneklerinde olduğu gibi kendi başına bir manaya delalet eden, zamanla ilgisi olmayan kelime türüdür. Fiil ise كتبَ (yazdı) يَكتُبْ (yazıyoryazacak) أكتبْ (yaz) misallerindeki gibi müstakil olarak bir manaya delaletinin yanı sıra zamanla da bağlantısı olan sözcük türüdür. ${ }^{1}$

Görüldüğü gibi fiilin zamanı ya mazi, ya hal ya da istikbaldir.2 İsmin zamanla ilgisi yok derken şu kaydı da düşmek durumundayız: İsmin zamana delaleti mümkündür; fakat bu, karineyle olur, fiildeki gibi kendiliğinden olmaz. ${ }^{3}$

Kendine has özellikleri olan isim ile fiil arasındaki farkları ana hatlarıyla şöyle sıralamamız mümkündür: عليٌّ مجتهُ "Ali çalışkandır." örneğinde olduğu gibi isimden haber verilebilir, yani ismin kendisi mübteda olabilir; fakat fiilden haber verilemez,

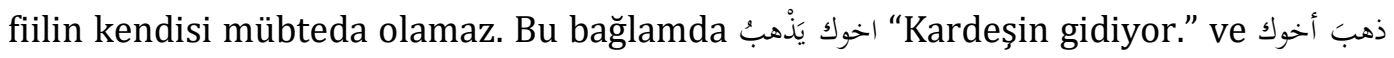
“Kardeșin gitti." cümleleri imkân dâhilinde iken يقومُ يجلسئ vهب يقوُ ifadeleri mümkün değildir.4 İsim ال takısı (الرجل), tenvin alabilir (فرسِ); başına cer (كتبت بالقلم) ve nida harfi

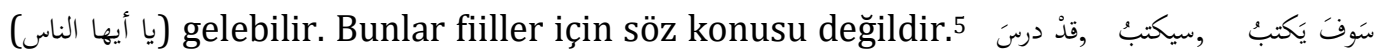
misallerinde olduğu gibi fiiller wوف ve wa warflerini alabilirken isimler almaz. ${ }^{6}$ Fiiller ذهبت örneğindeki gibi sakin müenneslik "ta”"sı ya da علمتُ علمتِ علمتُتُمْ cümlelerindeki gibi

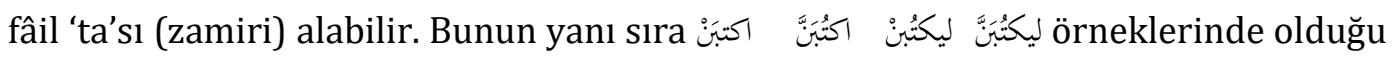

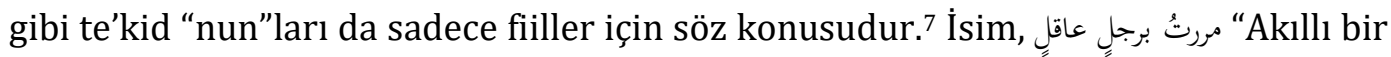
adama uğradım." örneğinde geçen (عاقِ) kelimesi gibi mevsuf olabilirken, fiil olmaz. Bu anlamda mesela عاقل kelimesi sıfat olarak يضْربُ عاقل يضل şeklinde kullanılmamaktadır. İsme dönen, işaret eden zamir olabilir; fakat fiile dönen, fiile işaret eden zamir olamaz. "Hasan'a ikramda bulundum, öğrenciyle karşılaştım." cümleleri

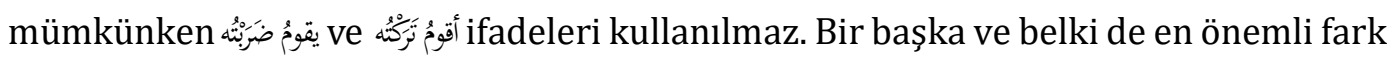

1 Cemâlüddin Abdülmelik b. Hișam İbn Hișâm, Şüzûrü’z-zeheb, ed. Berekât Yusuf Hebbûr (DımeșkBeyrut: Darü İbn Kesîr, 1434), 19; Mustafa Gâlâyînî, Camiü’d-durûsi'l- 'Arabiyye, thk. Ahmed İbrahim Zehve (Beyrut: Darü'l-Kitabi'l-'Arabî, 1430/2009), 17,18.

2 Ebû Bekr Muhammed b. Sehl b. Sirâc en-Nahvî el-Bağdadî İbn Sirâc, el-Usûl fínn-nahv (Beyrut: Müessesetü'r- Risâle, 1417/1996), 1/36.

3 Sa'düddin et-Teftâzânî, Muhtasarü's-Sa'd: Şerhü telhisi kitabi miftahi'l-ulûm, thk. Abdulhamid Handavî (Beyrut: el-Mektebetü'l-Asriyye, 1431/2010), 134.

Ibn Sirâc, el-Usûl fínn-nahv, 1/136.

Gâlâyînî, Camiü'd-durûs, 17.

İbn Sirâc, el-Usûl fínn-nahv, 1/38; Gâlâyînî, Camiü'd-durûs, 18.

Gâlâyînî, Camiü'd-durûs, 18. 
ismin يَضُعُ velimeleri ile kullanımı mümkün iken, fiilin mümkün değildir. Bu

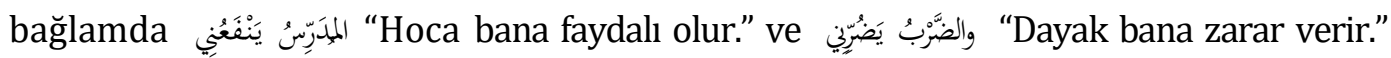

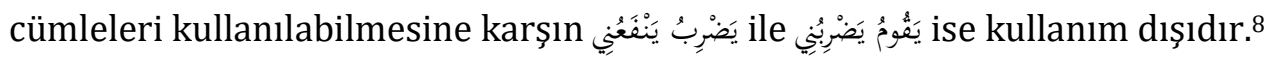

\subsection{Hudûs, Teceddüt, Sübût, Devam ve İstimrâr Kavramları}

Çalışma boyunca -özellikle de örnek getirilecek ayetlerde- حدوّد : حدوث (hudûs) (teceddüt), ثبوت (sübût), دوام (devam) ve استمرار (istimrâr) kelimeleri çokça قدام . قدام fiilinin zıddı olan حَدث- يحدُثُ fililinin masdarı olan hudûs kelimesi sözlükte "yeni" anlamındadır. ${ }^{9}$ Daha önce olmayan bir şeyin sonradan olmasıdır. ${ }^{10}$ Modern dönem Arap dilcilerinden Camiü'd-durûsi'l- 'Arabiyye adlı çok faydalı eser sahibi, Mustafa Gâlâyînî "hudûsu", "mevsufta bulunan mananın zamanın değişmesiyle yenilenmesidir" şeklinde tanımlamıştır.11 Ced (جدُّ) kökünden gelen "teceddüt" ise بحَََّدَ الشيْئُ bir şeyin yeni olması manasındadır.12 Kesik kesik gün yüzüne çıkma anlamındaki "teceddüt," bunun yanı sıra öncesi yokluk olan bir şeyin sonradan meydana gelme manasında da kullanılmaktadır.13 "Teceddüt" zaman mefhumunda bulunmaktadır. Zamanın cüzleri olan anın birleştirilmesi imkân dışıdır. Bu yüzden zamanın her anında vuku bulan fiil değișerek yenilenmektedir. ${ }^{14} \mathrm{Bu}$ söylediğimizi şöyle de ifade etmemiz mümkündür: Zamanın parçaları bir arada olmaz, aynı anda bulunmaz. Biri gider diğeri gelir, zaman da fiil mefhumunun bir cüz’üdür. Dolayısıyla fiil üç zamandan biriyle ilgili olmasının yanı sıra "teceddüt" de ifade eder denildiğinde bunlar kastedilmektedir. ${ }^{15}$

8 İbn Sirâc, el-Usûl fín-nahv, 1/38.

9 Muhammed Murtazâ Huseynî ez-Zebîdî, Tâcü'l-'arûs min cevahiri'l-kamûs (Kuveyt: Matbaatü Hukumeti'l-Kuveyt, 1385/1965), 5/205.

Ebü'l-Hüseyin Ahmed b. Fâris b. Zekeriyyâ İbn Fâris, Mu'cemü mekâyîsi'l-luga, thk. Enes Muhammed Şamî (Kâhire: Darü'l- Hadîs, 1429/2008), 199; Ebû Nasr İsmâil b. Hammâd Cevherî, es-Sıhâh: Tacü'l-lüga ve sıhâhü'l- 'Arabiyye, thk. Ahmed Abdülgâfur Attâr (Beyrut: Darü'l-illmi lilMelayîn, 1990), 1/278; Muhammed Ahmed b. Arafe Desûkî, Hâșiyetü't-Desûkî ala muhtasarı'sSa'd, thk. Halil İbrahim Halil (Beyrut: Dârü'l-Kütübi'l-İlmiyye, ts.), 173. Gâlâyînî, Camiü'd-durûs, 137.

12 Cevherî, es-Sihâh, 2/454; Ebü'l- Fazl Cemâlüddin Muhammed b. Mükerrem b. Ali b. Ahmed el Ensarî er-Rüveyfiî İbn Manzûr, Lisanü'l-'Arab, thk. Abdullah Ali el-Kebîr - Muhammed Ahmed Hasbillah (Kâhire: Darül-Me'ârif, ts.), 6/563; Mecdüddin Muhammed b. Ya`kub Fîrûzâbâdî, elKâmûsü'l-muhît, thk. Mektebetü Tahkîki't-Türâs fî Müesseseti'r-Risâle (Beyrut: Müessesetü'rRisâle, 1998), 271; Mecmau'l-lugati'l-Arabiyye Mecmau'l-lugati'l-Arabiyye, el-Mu'cemü'l-vasît, ed. İbrahim Mustafa - Ahmed Hasan Zeyyat (İstanbul: Çağrı Yayınları, 1996), 109.

13 Muhammedî el-Bamyânî, Durûs fíl'-belâga (Müessesetü'l-Belâg, 1429), 2/102; Hasan Duran Yunus İnanç, "Kur'ân-ı Kerîm'de Teceddüt ve Sübût Manası İçin Yapılan 'Udûl Çeşitleri”, Edebali Islamiyat Dergisi 3/5 (Mayıs 2019), 57.

14 Teftâzânî, Muhtasarü’s-Sa'd, 134; Duran - İnanç, "Kur'ân-ı Kerîm'de Teceddüt ve Sübût Manası İçin Yapılan 'Udûl Çeşitleri”, 57.

15 Teftâzânî, Muhtasarü's-Sa'd, 134. 
Tarîf b. Temîm el-Anberîye (öl. ?) ${ }^{16}$ ait olan bir beyitteki fiilin kullanımı teceddüt manasına güzel bir örnek olarak değerlendirilmektedir.

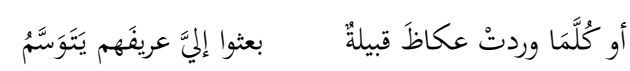

\section{Ukaz panayırına her gelişlerinde bana reislerini mi göndermektedirler o da} beni kolaçan edip durmakta. ${ }^{17}$

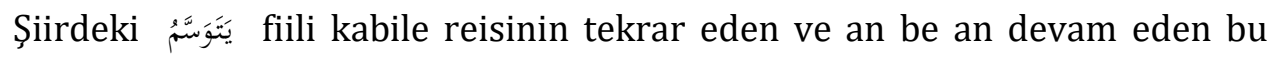
süreçte etrafını kontrol edip düşündüğü ve sağı solu tekrar tekrar araştırdığı

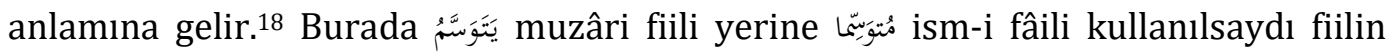
verdiği teceddüt anlamını vermeyecekti. ${ }^{19}$

Fiil teceddüt ifade eder derken bu, muzâri sigayla sınırlandırılmamakta, genel olarak kullanılmaktadır. Dolayısıyla teceddüt manası mazi fiil için de söz konusudur. Fakat teceddüt mazi fiille ilgili kullanıldığında sadece yokken meydana gelme anlamı söz konusudur. Mesela فتح fiili açma işine ve bu işin geçmiş zamanda yapıldığına delalet eder. Daha önce olmayan fiilin sonraki bir zaman diliminde olduğunu ifade/beyan etmektedir. ${ }^{20}$ İkinci mana yani fiilin kesik kesik meydana gelmesi anlamı mazi için söz konusu değildir.

"Bir yerde yerleşmek kalıcı olmak" manasındaki ثَبَ filinin masdarı olan²1 sübût ise mevsufta kalıcı, sabit, devamlı olana işaret eder. Mevsufta adeta tıynet, karakter halindedir. ${ }^{22}$ Bu sübût oluşta sadece o niteliğin onda olduğu bildirilir, fiildeki gibi teceddüt manası olmaz.

Bu bağlamda kullanılan "devam" kelimesine de temas etmek istiyoruz. "Devam" belli bir zaman dilimiyle kayıtlanmanın, "sübût" ise "teceddüt"ün mukabilidir. İsmin "sübût"a delaleti vaz’ı itibariyledir; fakat "devam"a delaleti bir karineyle gerçekleşir. ${ }^{23}$ Mesela زيٌّ منطقُ derken bu ifade sadece ve sadece gitme eylemini Zeyd'e isnad eder, burada devam manasının olup olmadığı ise karineden

16 Ölüm yılını tespit edemediğimiz Tarîf b. Temîm el-Anberî câhiliyye döneminde Temîm kabilesi içinde yaşamış şair ve savaşçılardandır. Muhammet Yekeler, Câhiliye Döneminden Hz. Peygamber Dönemi Sonuna Kadar Temîm Kabilesi (İstanbul: İstanbul Üniversitesi, Sosyal Bilimler Enstitüsü, Yüksek Lisans, 2014), 33.

17 Abdülkâhir el-Cürcânî, Delâilü'l-i'câz: Sözdizimi ve Anlambilim, çev. Osman Güman (İstanbul: Türkiye Yazma Eserler Kurumu Başkanlığı, 2015), 202.

18 Abdülkâhir el-Cürcânî, Delâilü'l-I'câz fî 'ilmi'l-me'ânî, thk. Seyyid Muhammed Reşit Ruzâ (Beyrut: Darü'l-Ma'rife, 1422/2001), 125.

19 el-Hatîb el-Kazvînî, el-Îzâh fî ulûmi'l-belâga: el-me'ânî ve'l-beyân ve'l-bedî' (Beyrut: Darü'lKütübi'l-İlmiyye, 1424/2003), 79.

20 Duran - İnanç, "Kur'ân-ı Kerîm'de Teceddüt ve Sübût Manası İçin Yapılan 'Udûl Çeşitleri”, 58. Mecmau'l-lugati'l-Arabiyye, el-Mu'cemü'l-vasît, 93.

Gâlâyînî, Camiü'd-durûs, 137.

Desûkî, Hâşiyetü't-Desûkî, 2/172. 
anlaşılır.24 Diğer yandan Nadr b. Cüeyye'nin (öl. ?) beytindeki25 منطق ism-i fâilinin sebatın yanında devama da işaret etmesi medh makamında olması hasebiyledir. ${ }^{26} \mathrm{Bir}$ şeyin daimi/devamlı oluşu onda aynı zamanda "sübût" olduğu anlamına gelir. Fakat "sübût" olan aynı zamanda "devam" da ifade eder denilemez. ${ }^{27}$ Bu noktada "devam" ile "istimrârın" aynı manada kullanıldığını söyleyebiliriz. ${ }^{28}$ Her ikisi de eylemin sürmesidir. Şu var ki "devam" isim ile, "istimrâr" fiil ile ilgili kullanılmaktadır. ${ }^{29}$ Fiilin "istimrâr" yenilenen zamanı ihtiva etmesi sebebiyle, ismin "devam" ifade etmesi ise makam iledir, yani medh ya da zem manası gözetildiğindedir. ${ }^{30}$ Fiilde "istimrâr" mazi sigada değil, muzâri sigada olur. ${ }^{31}$

\section{3. İsim ve Fiilin Kullanım Farklılıkları}

Bu açıklamalardan sonra isim ve fiilin bu özelliklerine temas edilebilir. İsimde sabitlik manası vardır, "teceddüt" yoktur; fiilde ise tam aksine "teceddüt" manası vardır. Mesela زيٌُْ منطلقُ denildiğinde gitme eyleminin Zeyd'de sabit olduğu düşünülür, mahiyete bir delalet vardır, "teceddüt" ve "hudûs" akla gelmez. ${ }^{32}$ Aksine buradaki

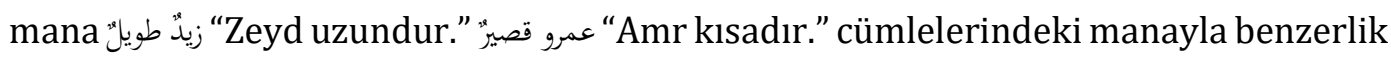
göstermektedir. ${ }^{33}$ Burada her iki kullanım yüzde yüz aynı olmasa da ism-i fâilli kullanım sıfat-ı müşebbeheli kullanıma benzetilmiştir. Yani mana sıfat-ı müşebbehede lazım,34 ism-i fâilde ise lazım gibidir.35 İsimde "sübût"un olması "teceddüt" ve üç zamanla sınırlı olmamasından kaynaklanmaktadır. ${ }^{36}$ İsimdeki bu

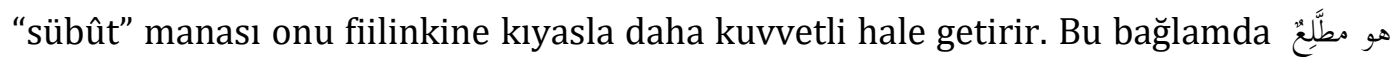

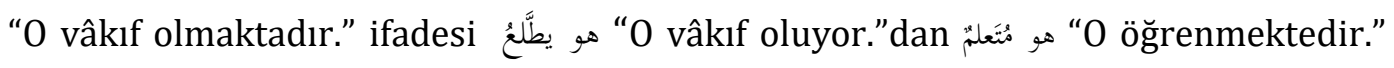

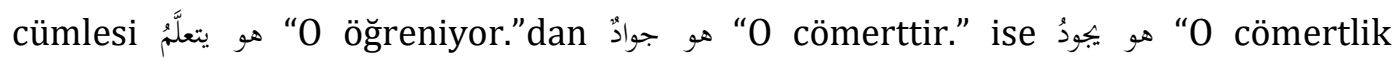
yapıyor." dan daha vurgu ve sebat (kalıcılık) ifade eder. ${ }^{37}$ Nadr b. Cüeyye'nin bir beytindeki isim kullanımı bu "sübût" manaya güzel bir örnektir:

$$
\text { لا يألف الدرهم المضروب صُرَّنَا لكن يمر عليها وهو منطلقُ }
$$

Bamyânî, Durûs fíl-belâga, 2/106.

Şiirin metni ve açıklaması bir sonraki paragrafta yer alıyor.

Desûkî, Hâşiyetü't-Desûkî, 2/173.

Desûkî, Hâșiyetü't-Desûkî, 2/172.

Desûkî, Hâşiyetü't-Desûkî, 2/174.

Desûkî, Hâş̧iyetü't-Desûkî, 2/174.

Desûkî, Hâşiyetü't-Desûkî, 2/174.

Teftâzânî, Muhtasarü's-Sa'd, 147; Desûkî, Hâşiyetü't-Desûkî, 2/230.

Cürcânî, Delâilü'l-I'câz, 123,124; Cürcânî, Sözdizimi ve Anlambilim, 198; Muhammed Fahrüddin Ziyâuddin Ömer er-Râzî, Nihayetü'l-îcâz fî dirâyeti'l-icâz, thk. Bekrî Şeyh Emin (Beyrut: Darü'lilmi lil-melayîn, 1985), 156.

Cürcânî, Delâilü'l-I'câz, 123,124; Cürcânî, Sözdizimi ve Anlambilim, 198.

Ondan ayrılmaz.

Bamyânî, Durûs fíl'l-belâga, 2/107.

Teftâzânî, Muhtasarü's-Sa'd, 135.

Fâdıl Sâlih es-Sâmerraî, Meâni'l-ebniye fíl- 'Arabiyye (Dımeşk-Beyrut: Darü İbn Kesîr, 1436/2015), 14. 
Basılmışs sikke bizim kesemize alışmaz; fakat geçiyorken şöyle bir uğrar.

Burada منطلقُ ism-i fâilinin yerine وهو ينطلقُ denilseydi bu, ismin ifade ettiği manayı karşılamazdı. ${ }^{38}$ Zira ism-i fâilin kullanılması bu geçmenin/gitmenin dirhem ile ilgili sabit olduğu, hep olduğu manası barındırmaktadır. ${ }^{39}$

Fiil kullanımına gelince mesela زيد هو ذا ينطقُ cümlesinde gitme eyleminin Zeyd tarafından azar azar gerçekleștiğinin ifade edilmesi kastedilmektedir. ${ }^{40}$ Bunun yanı sıra gitme isnadının belirli bir zamanda olduğuna işaret eder. Zira fiilde mahiyetin yanı sıra zamana da delalet vardır. Zamanla kayıtlı olan değişkendir, değişsenlik de teceddütü akla getirir. ${ }^{41}$ Çok tabidir ki bu farklılıklarından dolayı isimle fiil tamamen aynı anlamda kullanılamaz.

İsim ve fiilin birbiri yerine kullanılamayacağının bir örneği de A'şấnın (öl. $7 / 629$ [?]) şu beytindeki fiil kullanımıdır:

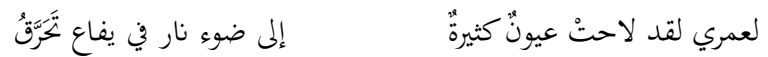

$$
\begin{aligned}
& \text { تُشَبُُ لمقرورين يصطلياها }
\end{aligned}
$$

Hayatıma yemin ederim ki bir tepede yanmakta olan, üşümüş ısınmaya çalışan iki kişi için tutuşturulmuş bir ateșin ışığına yönelmiş bakan birçok göz belirdi.

Cömertlik ve Muhallâk ${ }^{42}$ o ateşin başında geceledi. ${ }^{43}$

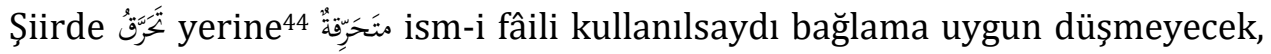
meramı tam ifade edemeyecekti. Bu, şiirin kafiyesinin bozulması sebebiyle değil ortamı betimlemeye uygun düşmeyişi sebebiyledir. ${ }^{45}$ Zira şiirde ocakta odun bulunduğu, aralıklarla ateşin odunla canlandırıldığı manası vardır. Eğer burada fiili yerine ism-i fâil kullanılsaydı bu niteliğin kalıcı olduğu bir ateşin varlığı anlamına gelecek, bu da büyük bir ateșin ışığına demek yerini tutacak ve sürmekte olan bir eylemi ifade etmeyecekti. ${ }^{46}$

Hûd Sûresinin 69. ayetindeki kullanımı da isimle fiil arasındaki farka örnek

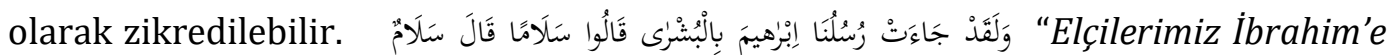
müjde ile gelip selam demişlerdi, o da selam diye mukabelede bulunmuștu." Buradaki

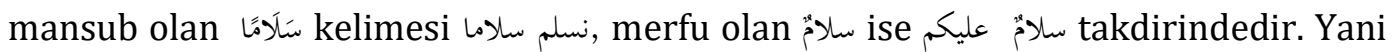

Kazvînî, el-Îzâh fî ulûmi'l-belâga, 79; Cürcânî, Sözdizimi ve Anlambilim, 198.

Teftâzânî, Muhtasarü's-Sa'd, 134; Desûkî, Hâşiyetü't-Desûkî, 2/173.

Cürcânî, Delâilü'l-i'câz, 123,124; Cürcânî, Sözdizimi ve Anlambilim, 198.

Râzî, Nihayetü'l-îcâz, 156.

Abdulaziz el-Kilabi, Cahiliye döneminde yaşamış cömert bir kimsedir. Atı onu ısırıp yüzünde halka gibi iz bıraktığı için المَّلَّقُ diye anılmıștır. Cürcânî, Delâilü'l-i 'câz, 125.

43 Cürcânî, Delâilü'l-i'câz, 125.

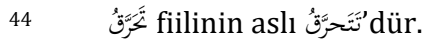

45 Cürcânî, Delâilü'l-i'câz, 125; Cürcânî, Sözdizimi ve Anlambilim, 200.

46 Cürcânî, Delâilü'l-i'câz, 125; Cürcânî, Sözdizimi ve Anlambilim, 202. 
ilki fiil cümlesi, ikincisi isim cümlesi takdirindedir. Melekler "hudûs"a delalet eden fiille selamlamış, İbrahim peygamber ise "sübût"a delalet eden isimle mukabelede bulunmuştur. Buradan İbrahim peygamberin meleklerin selamına daha güzeliyle karşılık verdiğini anlamaktayız. ${ }^{47}$

فإِذا لقيُُّ الذّين كفروا فَضَرْبَ الرِّقاب "Küfredenlerle karşılaştığınız vakit onların boyunlarını vurun.” Ayetteki ضرب kelimesi mansub gelmiştir. Bu, hazfedilen bir fiil olduğunu gösterir. Yani ifade فاضربوا ضربا takdirindedir. Darb kelimesinin "sübût" anlamına (isim) işaret eden merfu hali gelmemiştir; çünkü "boynun vurulması" geçicidir, savaşla sınırlıdır daimî bir durum değildir.48

Bakara Sûresinin 14. ayetindeki isim ve fiil kullanımını da bir başka örnek

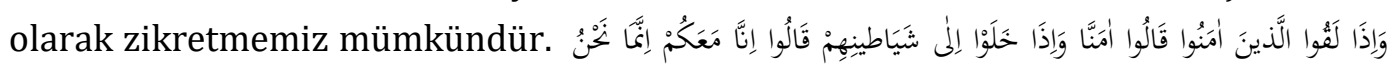
"Müminlerle karşllaştıklarında iman ettik derler, şeytanlarıyla baş başa kaldıklarında biz sizinle beraberiz sadece dalga geçiyoruz." Burada münafıkların müminlere hitabı "hudûs" manası barındıran fiille ifade edilmiş, kendi yandaşlarına hitapları için ise te'kid ile beraber "sübut" ve "devam"a işaret eden isim sigası kullanılmıştır. ${ }^{49}$ Zira münafıklar içlerinden gelmediği için müminlere karşı "sübut" ifade eden isimle hitap edememişler, kendi yandaşlarına ise gönül rahatlığı ile içlerinden gelerek isim sigasıyla söyleyeceklerini söylemişlerdir. ${ }^{50}$

Bu bağlamda şu hususu hatırlatmada yarar görüyoruz. "Sübût" ya da "hudûs" ifade eden isim cümlesi ya da fiil cümlesi değildir. Cümlede bulunan isim veya fiilin

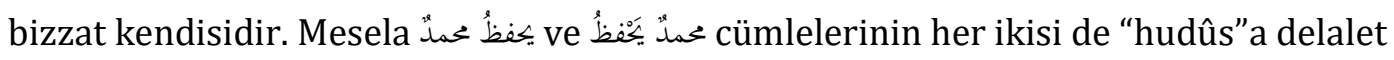
eder. İkinci cümlede ismin öne alınması ihtisas, şüpheyi giderme veya başka bir sebebe bağlıdır. Delalet bakımından her iki cümle benzerdir. ${ }^{51}$ Eğer bizzat cümlenin kendisi "sübût" ya da "hudûs"a delalet etseydi محمدُ ينطلقُ ,محمدُ انطلقَ معمدُ منطلقُ cümleleri arasında bir fark olmazdı; zira üçü de isim cümlesidir. ${ }^{52}$ Nitekim Zerkeşî (öl. 794/1392) el-Burhân fì ulûmi'l-Kur'ân isimli eserinde bu konuya bir başlık açmış orada, isim ya da fiil cümlesinden bahsetmeyerek fiil "teceddüt" ve "hudûs"a, isim ise

47 Ebûl'l-Kâsım Cârullah Mahmud b. Ömer b. Muhammed ez-Zemahșerî, el-Keșşâf an hakâiki gavamizi't-Tenzîl ve uyûni'l-ekâvîl fî vücûhi't-te'vil, ed. Muhammed Abdüsselam Şâhîn (Beyrut: Darü'l-Kütübi'l-İlmiyye, 1995), 4/391; Sâmerraî, Meâni'l-ebniye, 15; Fâdıl Sâlih es-Sâmerraî, elCümletü'l- 'Arabiyye te'lifuhâ ve aksâmuhâ (Amman: Darü'l-Fikr, 1427/2007), 165. Fâdıl Sâlih es-Sâmerraî, et-Ta'biru'l-Kur'anî (Ammân: Daru Ammâr, 1427), 33.

Zemahșerî, el-Keşşâff, 1/73.

Zemahșerî, el-Keșşâf, 1/73.

Sâmerraî, el-Cümletü'l-'Arabiyye, 162; Sâmerraî, Meâni'l-ebniye, 17.

Sâmerraî, el-Cümletü'l-'Arabiyye, 163. 
"sübût"a delalet eder; bunların birbirleri yerine kullanılması uygun düşmez şeklinde değerlendirmede bulunmuştur. ${ }^{53}$

\section{4. İsm-i Fâil}

Araştırmanın temel kavramlarından ism-i fâilin Arap dilindeki kullanımına temas etmenin örneklerin daha iyi anlaşılmasına katkı sağlayacağını düşünmekteyiz. Türetilmiş bir isim olan ism-i fâil masdarın ifade ettiği anlama, ${ }^{54}$ bu anlamın geçici oluşuna ve fâiline işaret eder. 55 Örnek olarak جالس kelimesi masdar olan جلوس va ve bu mananın geçiciliğine,56 -zira جلوس hep sahibiyle beraber değildir - bir de جلوس gerçekleștirene delalet eder. ${ }^{57}$ Bu noktada şu hususu ifade etmede fayda görmekteyiz: Kalıcılığı/sebatı daimi olana yaklaşana kadar devam eden eylem de geçici sayılmaktadır. ${ }^{58}$ Ayrıca ism-i fâilde anlamın geçici oluşu her zaman söz konusu

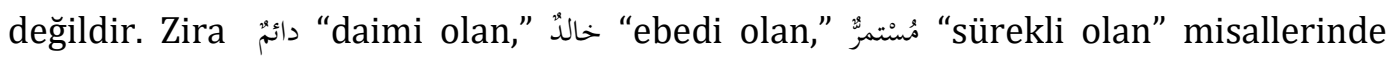
görüldügü üzere daimî anlam da söz konusu olabilir. ${ }^{59}$

İsm-i fâilin sarf açısından nasıl türetildiğine kısa da olsa değinmenin isabetli olacağını düşünmekteyiz. Üçlü yalın fiillerin ism-i fâili vن vezninde gelir.60 Bunun dışında kalan fiillerinki ise şöyle yapılır: Muzâri fiilin başında bulunan müzaraat harfinin yerine ötreli bir mim harfi getirilir, en sondan bir önceki harf de esre

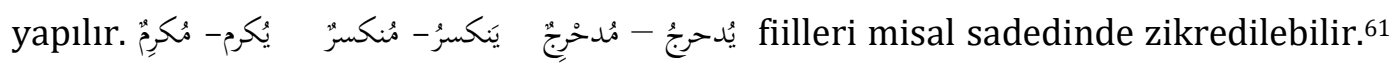
Arapça'da ism-i fâili bu kaidenin dışında gelen ${ }^{62}$ fiil sayısı oldukça azdır. ${ }^{63}$

İsm-i fâilin fiil gibi fonksiyonu vardır. Hatta Kûfe dil okulu fiil olarak değerlendirmektedir.64 İsm-i fâilin muzâri fiil gibi işlevde bulunması/amel etmesi harekeli ve sakin olma yönünden aralarındaki iki yönlü benzerlik dolayısıyladır.

53 Bedrüddin Muhammed b. Abdullah ez-Zerkeșî, el-Burhân fî Ulûmi'l-Kur'an, thk. Ebû'l-Fadl Dimyatî (Kâhire: Darü'l-Hadîs, 1427/2006), 960.

54 Bu, hades (حدث) olarak isimlendirilmektedir.

Abbas Hasan, en-Nahvü'l-vafí (Tahran: Avand Danîş, 1425/2004), 3/187.

Bu, hudûs (حدوث) olarak isimlendirilmektedir.

Sâmerraî, Meâni'l-ebniye, 45.

Abbas Hasan, en-Nahvü'l-vafî, 3/187; Sedat Sağdıç, “Arap Dilinde İsm- Fâilin Kullanımı ve Kur’an Meallerindeki Tercüme Problemleri", Kavramlar ve Kuramlar: Dil Bilimleri (Mardin: Mardin Artuklu Üniversitesi Yayınları, 2020), 501.

59 Abbas Hasan, en-Nahvü'l-vafì, 3/188.

Abduh er-Râcihî, et-Tatbîkü's-sarfî (Riyad: Mektebetü'l- Meârif, 1420/1999), 66; Reşîd eș-Șertûnî, Mebâdiü'l- 'Arabiyye, ed. Hâmid el-Muhammedî (Tahran: Darü'l-İlm, 2011), 2/57.

er-Râcihî, et-Tatbîkü's-sarfî, 67; Şertûnî, Mebâdiü'l-Arabiyye, 2/58.

er-Râcihî, et-Tatbîkü's-sarfí, 64.

Mesela أسهبَ (ayrıntılı olarak anlattı) fiilinin ism-i fâili أحصنَ, مُسسهَبْ (sağlam, dayanıklı yaptı) fiilinin

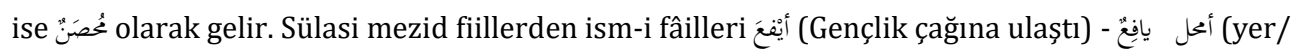
toprak verimsiz, hale geldi) - ماحلٌ misallerindeki gibi kural dışı olarak فاعلٌ biçiminde gelenleri de vardır.

64 Fâdıl Sâlih es-Sâmerrâî, Me'ânî́n-nahv (Beyrut: Darü ihyâ, et-Türâsi'l- 'Arabiyyi, 1428/2007), $3 / 147$. 
Örnek olarak كاتبْ sözcüğg̈ يكتبُ 'ya benzemektedir. Zira iki kelimenin de harf sayısı dört, ikinci harfleri sakin diğerleri ise harekelidir. İsm-i fâilin fiile benzerliği, hem lafız hem de anlam yönündendir.65 Zaten muzâri sözcüğünün (مضارع kökeni de bunu göstermektedir. Çünkü ضارعَ- يضارعُ filinin ism-i fâili olan مضارع kelimesi "benzeyen" manasina gelmektedir.66

İsm-i fâilin başka bir kelimede etki etmesini (amel etmesini) genel olarak ال (elif lam) takısı alıp almama durumuna göre gruplandırabiliriz. İsm-i fâil ال takılı ise başka herhangi bir şeye gereksinim duymadan geçmiş, şimdiki ya da gelecek zaman ذَهبَ المُنْفِقُ الفقراءً "Fakirlere dün infak eden/şu an infak ediyor olan/yarın infak edecek olan gitti."67 cümlesindeki gibi bağlamdan çıkarılır.68 Geçmiş, şimdiki veya gelecek zaman manası içeren ال takısı almış ism-i fâilin muzaf olarak görev yapması da imkân dâhilindedir.69 Zikri geçen misal ذَهبَ المُنْفِقُ الفقراءٍ أمس أو الآن أو غدا olarak da kullanılabilir.70 İsm-i fâilde ال takısı yoksa işlev görmesi için en başta şimdiki veya gelecek zaman ما خارجّ عَمُكَكَ من البيتِ “Amcan evden çıkmıyor." misalindeki gibi olumsuzluk veya هل مُتِْنْ خالك عمله "Dayın işini sağlam yapıyor mu?" tümcesinde olduğu üzere soru geçmesi gerekir. Veya ism-i fâil " يوسفُ دارسٌ ولداه في الجامعة "Yusuf'un iki çocuğu üniversitede okuyor." sözünde olduğu

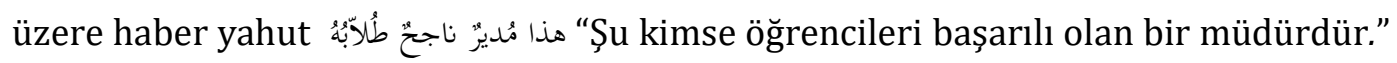

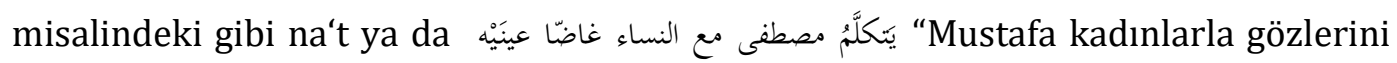
kısarak konuşuyor." cümlesindeki gibi hal olmalıdır.72 Gramer âlimlerinden bu zikredilen şartlara ism-i fâilin nida harfinden sonra gelmesi gerektiğini ekleyenler de vardır. ${ }^{73}$ Hemen ifade edelim ki nahiv bilginlerin çoğunluğu bunu na't şartıyla aynı

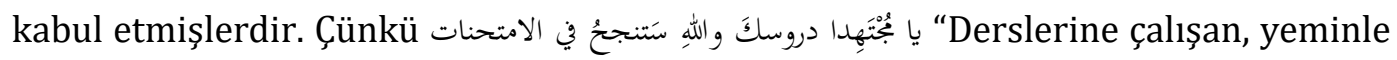

\footnotetext{
65 Behâü'ddin Abdullah İbn Akîl, Șerhu İbn Akîl alâ elfiyeti İbn Mâlik, ed. Muhammed Muhyiddin Abdulhamîd (Dımeşk: Darü’l-Fikr, ts.), 3/106; Sağdıç, “Arap Dilinde İsm- Fâilin Kullanımı”, 503. İbn Akîl, Şerhu İbn Akîl, 3/106.

67 İbn Akîl, Şerhu İbn Akîl, 3, s. 110; Mustafa Galâyînî, Câmiu'd-durûsi'l-Arabiyye, (Beyrut: Darü'lkitabi'l-Arabi, 1009), 3, 593.

İbn Akîl, Şerhu İbn Akîl, 3, 110.

Sertûnî, Mebâdiü'l-Arabiyye, 4 (Nahiv), 167.

El takılı isim muzaf olabilmiştir. Zira hakiki olmayan izafette (lafzî, mecazi, gayri mahza) muzaf; ikil ve cemi müzekkeri salim olarak gelmesi veya el takılı bir isme muzaf bulunması koşuluyla el takısı kabul edebilir. Şertûnî, Mebâdiü'l-Arabiyye, 4 (Nahiv), 167; Galâyînî, Câmiu'd-durûsi'l-Arabiyye, 593; Sâmerrâî, Meânî̀n-nahv, 3, 147.

72 Şertûnî, Mebâdiü'l-Arabiyye, 4 (Nahiv), 167; Galâyînî, Câmiu'd-durûsi'l-Arabiyye, 593; Sâmerrâî, Meânî̀n-nahv, 3, 147.

73 Abbas Hasan, en-Nahvü'l- vâfî, 3, 195; Sâmerrâî, Meânînn-nahv, 3, 147.
} 


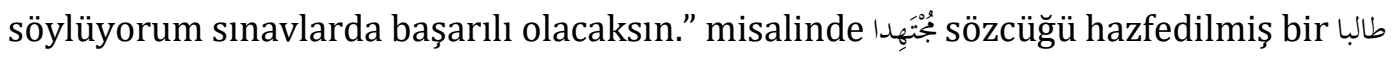
kelimesinin na'tı pozisyonundadır. ${ }^{74}$ Ayrıca ism-i fâilin, küçültme ismi ${ }^{75}$ kalıbında olmaması şarttır. Zira ism-i fâil, küçültülen isim olursa başka bir kelimede etki etme şartı yerine getirilmemiş olur. Bu hususu dikkate aldığımızda يأَي قُوَيْنُِّ، رجلا sözünün uygun olmadığını ifade edebiliriz. ${ }^{76}$ İsm-i fâilin işlev görmesi için öne sürülen bu şartlar i'timad (الاعتماد) olarak isimlendirilir. Burada şu hususu zikretmek zorunludur ki أذاهبةٌ النساءُ أمسِِ "Kadınlar dün gittiler mi”?77 misalindeki gibi ism-i fâilin ref olarak işlev görebilmesi için şimdiki ya da gelecek zaman anlamı zorunlu değildir, i'timad şartı kâfidir. Dahası ism-i fâilin fâili gizli veya açık zamir ise ism-i fâilin işlevi için i'timad gerekli de değildir. Bunun anlamı şudur: Zikredilen şartlar ism-i fâilin etkide bulunduğu isin, açlk fâil veya mef'ulü bih olduğunda söz konusudur. ${ }^{78} \mathrm{Bu}$ söylenilenlerden şu neticeyi elde etmek imkân dâhilindedir İsm-i fâilin mef'ulünün bulunması şimdiki ya da gelecek zaman anlamında olmasıyla ilişkilidir. $\mathrm{Bu}$ anlamlarda kullanılmıyorsa mef'ulü olmaz. هو هنقُ أباكَ sözü "O babana infakta bulunuyor/bulunacak." anlamına gelir. Şayet infak geçmişte olmuşsa هو مُنْفِقُ أبيكَ هن "O, babana infak etti./O, babana ikram edendir." misalinde olduğu üzere muzaf olarak gelme şartı vardır. ${ }^{79}$

İsm-i fâilin şimdiki ya da gelecek zaman anlamında gelmesi iki türlüdür. En sık

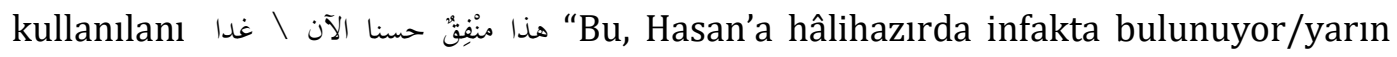
infakta bulunacak." misalindeki gibi kendisinin nekre olarak sonrasında gelen ismi nasb etmesidir. Sık kullanım tarzı böyle olmasının yanı sıra ism-i fâil tenvinsiz, muzaf

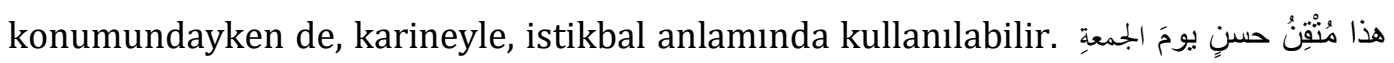
يوَ بمu, Hasan'a önümüzdeki Cuma günü infakta bulunacak.” örneğinde karine المقبلِ

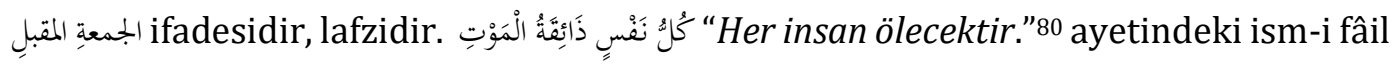
de istikbal anlamı barındırmaktadır. ${ }^{81}$ Buradaki karine ise mana ile ilgilidir, siyak sibaktan çıkarılır. Zira ayetin öncesinde Hz. Muhammed'e seslenilerek hiçbir canlının baki olmadığı bildirilmekte, sonrasında da bu umumi kaide söylenmektedir. Bunlardan şöyle bir netice hâsıl olmaktadır. İsm-i fâil muzaf olduğunda geçmiş zaman dışında bir anlamda kullanılmayacak diye bir genellemede bulunulamaz. Maziyle beraber şimdiki ve gelecek zamana da işaret etme ihtimali vardır. ${ }^{82}$ Fakat ism-i fâilin sonrasında gelen ismin mansub olduğu durumlarda ise şimdiki ve gelecek zamanın

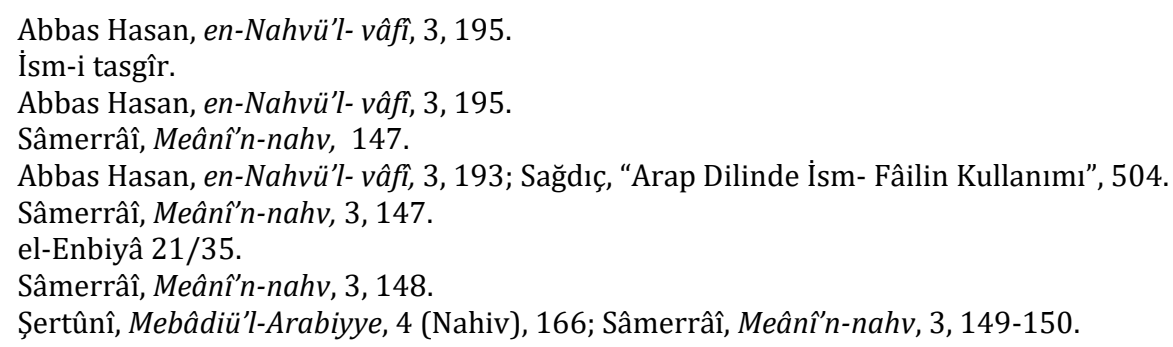


dışında bir anlam için kullanılamaz. ${ }^{83}$ İsm-i fâil tenvinli olup mef ulü nasb ettiğinde şimdiki veya gelecek zaman anlamına geldiğini önceki satırlarda aktarmıştık. Bu sebeple kullanımı sahih kabul edilmemektedir. ${ }^{84}$ Bu noktada şunu da ifade edelim ki geçmiş zaman anlamında olduğu durumda da mef'ul alması mümkündür. Şimdiki ve gelecek değil, geçmiş anlamlı olduğu halde mef ulü nasb etmesinin tek bir koşulu vardır. 0 da i'timadla beraber ism-i fâilin yerine muzâri filin getirilmesinin imkan dâhilinde olması ve getirildiğinde anlamı bozmamasıdır. Mesela كانت الثلوجُ أمس مُغَِِيّةً الحقولَ مُصَفِيِة الهواءً fâillerin yerine تُصَفِّي تُعَبِّ fiillerinin kullanılması manayı bozmamaktadır. Fakat هذا

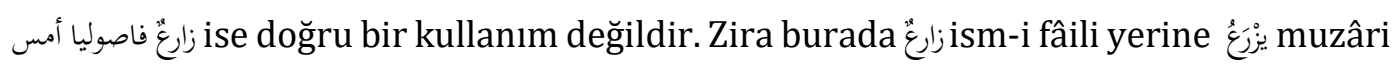
getirilmesi uygun değildir. ${ }^{85}$

Bu saydıklarımızdan başka ism-i fâilin bir takım özelliklerine değinmenin yararlı olacağınız düşünmekteyiz. İsm-i fâilin mef'ulünün $J$ harf-i cerri alması

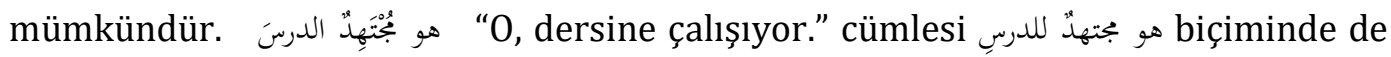
kullanılabilir.86 İsm-i fâilin ism-i mef'ul anlamında geldiği de görülmektedir. Hicivleriyle tanınan muhadram şair Hutay'e'in (öl. 59/678 [?]) bir beytindeki kullanım buna örnektir:

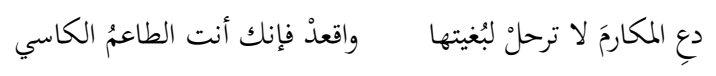

Sen cömertliği bırak, ondan uzak ol, otur oturduğun yerde.

Zira sen yedirilip giydirilen bir kimsesin.

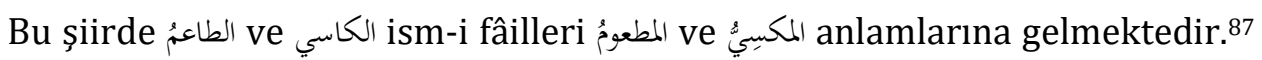

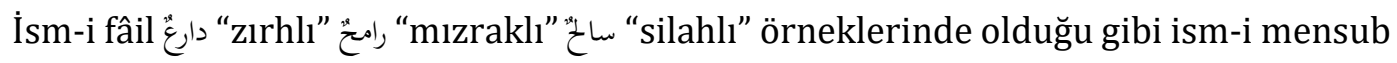
anlamında da kullanılabilir.88 İsm-i fâilin birden çok mef'ulü olduğunda المؤمنُ مُكرٌُ المسكينِ طعام "Mümin, miskin kimseye yemek ikramında bulunur." cümlesindeki gibi ilkine izafe edilir, diğerleri mansub olur. İlk mef ulün nasbı şeklindeki kullanım ( المؤمنُ مُكْرِمِ (المسكينَ طعاماً ) da imkân dâhilindedir.89

İsm-i fâilin muzafı ileyhine atfedilen sözcük, هذا ضارب محمدٍ وخالدٍ اخالدا örneğindeki gibi mecrur da mansup ta gelebilir. Bununla beraber sık kullanılanı cerli atıftır, bu şekil kullanımında bir sorun bulunmamaktadır. Lakin nasblı atıfta murad edilen

Sâmerrâî, Meânî́n-nahv, 3, 149-150.

Sâmerrâî, Meânînn-nahv, 3, 147.

Abbas Hasan, en-Nahvü'l- vâfî, 3, 194. Sağdıç, “Arap Dilinde İsm- Fâilin Kullanımı”, 505.

Abbas Hasan, en-Nahvü'l-vâfî, 3, 199.

Ahmed el-Hamlâvî, Şeze'l-'arffí fenni's- sarf (Beyrut: el-Mektebetü'l-Asriyye, 2007), 86.

Sâmerrâî, Meânî̀l-ebniye fi'l-Arabiyye, 51.

Şertûnî, Mebâdiü’l-Arabiyye, 4 (Nahiv), 167, 168; Sağdıç, “Arap Dilinde İsm- Fâilin Kullanımı”, 506. 
geçmiş zaman anlamı olursa bu durumda atfedilenden önce mazi manalı bir fiil takdir edilir. أنا ناصحُ عليٍّ وبكراً cümlesi أنا ناصحُ عليّ ونصحتُ بكرا takdirindedir. Eğer muzâri anlama niyet edilirse, ya muzâri bir fiil ya da tenvinli/nekre ism-i fâil takdir edilir. انا ناصحُ عليٍّ cümlesi de وبكرا غدا takdirindedir.

İzafetli kullanımda gerçekleşen atıfla ilgili, yaşayan dil âlimlerinden Fâzıl Sâlih Sâmerrâî’nin tespitlerini zikretmenin faydalı olacağını düşünmekteyiz: Eğer cer halindeki bir isme nasblı bir atıf yapılmışsa mananın geçmiş zaman olduğuna dair de karine yoksa izafetli olanın anlamı ihtimalli, nasb biçimindekinin ise kat'idir. Örneğin misalinde Ali'ye nasihat edilmesi geçmiş, şimdiki ve gelecek zaman anlamlarına ihtimallidir. Gelgelelim Bekir'e nasihat edilmesi ise şimdiki ve gelecek zaman dışındakine açık değildir.90 Ama şayet هو ناصحُ عليٍّ وبكرا أمس misalindeki gibi bütün hepsinin geçmişte vuku bulduğuna dair bir karine mevcutsa, atfedilenden önce geçmiş zaman anlamlı bir fiil (ونصحتُ) takdir edilir. Bu durumda ise ism-i fâilli kullanım sübut, fiille olan ise teceddüt anlamı ihtiva eder. ${ }^{91}$

İsm-i fâil muzaf olarak kullanıldığında isim anlamı oluş anlamından daha kuvvetli olur. Örneğin السائق sözcüğüyle şoför الكاتب ile yazar, الحارس ile bekçi murad edilebilir. هذا سائقُ الحافلِ "Bu kimse otobüsün sürücüsü/şoförüdür." جاءَ حارسئ الشركة "Şirketin koruyucusu/güvenliği geldi.” örneklerindeki gibi isim manası öne çıkmaktadır. Zira izafet ismin niteliğidir. Fakat هذا سائقُ الحافلة "Bu kimse otobüsü sürüyor." هذا حارس الشركة "Bu kimse şirketi koruyor." misallerinde görüldüğü gibi ism-i fâil mef ul aldığında durum farklılaşır. Bu durumda ise oluşa bir delalet vardır. ${ }^{92}$

\section{5. İsm-i Fâil ile Fiil Farklılıkları}

Fiil sigasında bulunmayan "sübût"/kalıcılık ism-i fâilde bulunur.93 Hemen ifade edelim ki bu, önceki satırlarda ifade ettiğimiz ism-i fâil "hudûs"a delalet eder tespitiyle çelişmez. Zira bütün isimler "sübût"a delalet noktasında aynı derecede değildir. İsm-i fâilin bu özelliği fiile göredir, mübalağa ism-i fâil ve sıfat-ı müşebbehe ile kıyaslandığında ise "sübût" ifade etmez, "hudûs"a işaret eder. ${ }^{94}$ Bu söylediğimizi bir örnek üzerinden daha da açık hale getirelim: قائم ism-i fâili قامَ yahut'dan daha devamll, sabittir. Fakat bunun sübûtu mesela bir طويل yahut "قصير kadar değildir. Zira ayaktaki birisi oturan olabilir; fakat uzun yahut kısa bir kimsede değişiklik olmaz hep öyledirler.95 İsm-i fâilde aslolan "hudûs"tur, "sübut" manası (sübûtun kastedilmesi)

Sâmerrâî, Meânî́n-nahv, 3, 151, 152.

Sâmerrâî, Meânî”n-nahv, 3, 152; Sağdıç, “Arap Dilinde İsm- Fâilin Kullanımı”, 506.

Sâmerrâî, Meânî́n-nahv, 3, 150-151; Sağdıç, “Arap Dilinde İsm- Fâilin Kullanımı”, 506, 507.

Sâmerraî, Meâni'l-ebniye, 10.

Sâmerraî, Meâni'l-ebniye, 46.

Sâmerraî, Meâni'l-ebniye, 46. 
ise geçicidir.96 Aslında bazı tanımlarda bu farklılığa işaret edilmektedir. "Hudûs"; geçici olan, daimi olmayan şeklindeki tanımının yanı sıra sebatı ve kalıcılığı neredeyse daimi olana yaklaşan şeklinde de tanımlanmaktadır. ${ }^{97}$

İsm-i fâil, fiil gibi kullanılmasına rağmen aralarında isim ve fiil olma yönlerinden farklılıklar vardır. Önceki satırlarda defaatle ifade ettiğimiz gibi isim "sübût", fiil ise teceddüt ve "hudûs" ifade eder. Mesela يوسفُ مكرمّ ile يكرم يوسفُ tamamen aynı anlama gelmezler. Bunun sebebi fiilin zamanla kayıtlı olmasıdır; mâzi fiil geçmiş zaman ile, muzâri fiil ise şimdiki zaman yahut gelecek zaman ile kayıtlıdır. Öte yandan isim zamanla kayıtlı olmadığı için daha kapsamlı, genel ve sabittir. ${ }^{98}$ Bundan dolayı daha kalıcı bir manaya işaret etsin diye bazen fiilden isme dönülür. Bu söylediklerimizi bir örnek üzerinden daha netleştirebiliriz. Bir kişinin, arkadaşının

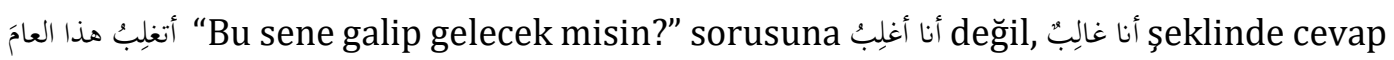
vermesi fiille verilecek cevaba kıyasla vurgu içerir. Zira burada kendine güveninden dolayı böyle cevaplandırmakta, galip gelme tamamlanmış gibi muhatabına o işi olmuş

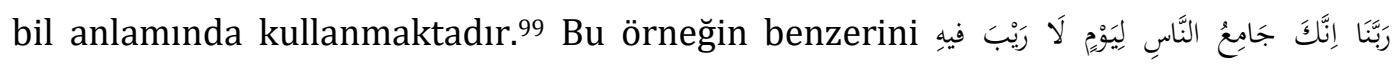
"Rabbimiz (geleceğinden) şüphe duyulmayan o günde sen insanları bir araya getireceksin."100 ayetinde görmekteyiz. Burada din günü/hesap günü kesin gerçekleşeceği için بَّمَّمُ fiili yerine sübûta delalet eden ism-i fâili kullanılmıştır. Benzer kullanım وانَّ الدّينَ لواقع "Hesap günü mutlaka gelecektir.”101 ayetinde de mevcuttur. ${ }^{102}$ İsimle fiil arasındaki kullanım farkına işaret eden Râzî̀nin (öl. 606/1210) değerlendirmeleri de bu minvaldedir: "İsm-i fâil çok yerde masdarın sübûtuna, kalıcılığına işaret eder, fiil de ise böyle bir mana yoktur. فلانٌ فلان شربَ الخمر ile

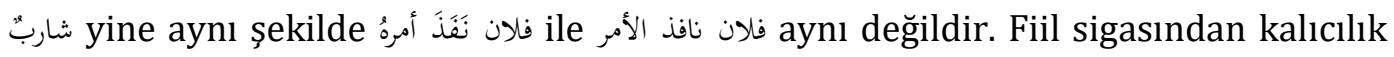
anlaşılmaz; fakat isim sigasında böyle bir mana vardır."103

\section{Kur'an'da İsm-i Fâil ile Fiil Kullanımı}

\section{1. Örnek: el-Bakara, $2 / 14,15$}

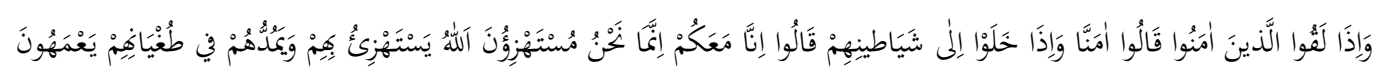

Sâmerraî, Meâni'l-ebniye, 48.

Abbas Hasan, en-Nahvü'l-vafi, 3/187.

Sâmerraî, Meâni'l-ebniye, 9.

Sâmerraî, Meâni'l-ebniye, 14.

Âl-i İmrân 3/9.

ez-Zâriyât 51/6.

Sâmerraî, Meâni'l-ebniye, 14.

Muhammed Fahrüddin Ziyâuddin Ömer er-Râzî, Tefsîrü'l-fahri'r-Râzî: et-Tefsîrü'l-kebîr: Mefâtîhü'l-gayb (Beyrut: Dârü'l-Fikr, ts.), 25/30. 
Ayet-i kerimede münafıkların istihzası ile ilgili ism-i fâil, Allah'ın istihzası ${ }^{104}$ ile ilgiliyle fiil sigası kullanılmaktadır. Burada münafıklarla ilgili ism-i fâil kullanılması onlarda istihza özelliğinin kalıcı olması, adeta karakter haline gelmesi sebebiyledir. ${ }^{105}$ Allah ile ilgili "teceddüt" manası ifade eden fiil kullanılması ise azap gelinceye kadar Allah'ın onlara mühlet verdiğine işaret eder. Bu da Müslümanlara yönelik şöyle bir mesaj da içermektedir: Nifak ehlinin nimet içerisinde olması -her ne kadar uzun olsa da - onlara süre tanımaktan başka bir şey değildir. ${ }^{106}$ Ayrıca bu kullanımdan istihzanın tekrarlandığını anlamaktayız. ${ }^{107}$ Burada Allah onlara adeta sizin bu haliniz devam ettikçe benim de size tavrım böyle olacaktır mesajını vermektedir. ${ }^{108}$ Bu tercih daha etkili olması sebebiyledir. Zira birinci bölümde birçok kez dikkat çektiğimiz gibi fiil "teceddüt", isim ise "sübut" ifade eder. Buradaki istihza onları cezalandırmaktır. ${ }^{109} \mathrm{Bu}$ cezalandırma sürekli olursa, cezalandırılan ona bir ünsiyet kazanır ve böylelikle verilen ceza etkisini yitirir. ${ }^{110}$ Nefis buna alışır bir süre sonra fazla da etkilenmez. Böyle bir cezalandırmanın daha etkili, daha elem verici olduğu fiil sigasının kullanılmasından anlaşılmaktadır. ${ }^{111}$ Türkçemizde "Battı balık yan gider" deyimiyle ifade edilen insanların durumuyla benzerlik göstermektedir. Bu sebeple an be an yenilenme manası veren fiil ifadesi kullanılmıştır. ${ }^{112}$ Ayrıca "teceddüt" ifade eden fiilin kullanılması istihzanın tek çeşit değil, farklı farklı olduğunu gösterir.113

\section{2. Örnek: el-Bakara, $2 / 30$}

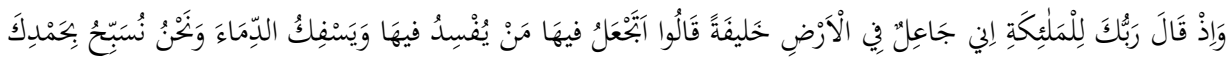

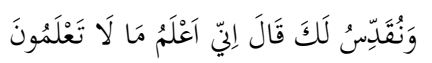

Ayet-i kerimede Allah'ın "yaratacağım" sözü ile ilgili ism-i fâil, meleklerin buna mukabelesinde ise fiil sigası kullanılmıştır. Bu kullanımda nükte vardır. Allah'ın ilmi mutlak olduğu için buna işaret eden "sübut" mana barındıran ism-i fâil, meleklerin ilmi ise Allah'ınkine kıyasla kusurlu ve eksik olduğu için fiil sigası kullanılmıştır. Ayrıca birinci bölümde belirttiğimiz gibi ism-i fâil sigasının kullanılmasında yaratmanın kaçınılmaz olarak gerçekleşeceğine bir işaret vardır,

104 Allah'ın istihzası onları cezalandırmak manasındadır, Müşâkele sanatı vardır. Geniş bilgi için bkz. M. Faruk Çifçi, "Kemalpaşazâde'ye Göre Müşâkele Sanatı (Problemler ve Eleştiriler)", Hitit Üniversitesi İlahiyat Fakültesi Dergisi 9 (2020).

105 Muhammed Tâhir İbn Âșûr, Tefsîrü't-tahrîr ve't-tenvîr (Tunus: ed-Dârü't-Tunisiyye, 1984), 1/294.

106 İbn Âșûr, Tefsîrü't-tahrîr ve't-tenvîr, 1/294.

107 Zemahșerî, el-Keșşâf, 1/75; Râzî, Tefsîrü'l-fahri'r-Râzî, 2/78; Teftâzânî, Muhtasarü's-Sa'd, 148.

108 Şerefüddin el-Huseyn b. Abdillah et-Tîbî, Fütûhu'l-gayb fíll-keșfan kınâi'r-reyb (Ebû Dabî: Caizetü Dübey ed-Devliyye li'l Kur'ani'l-Kerim, 1434/2013), 2/206.

109 Ebû'l-fazl Şihâbüddîn es-Seyyid Mahmud Âlûsî, Rûhu'l-me ânî fî tefsîri'l-Kur'ani'l- 'Azîm ve Seb 'i’lMesânî (Beyrut: İdâretü't-Tibâati'l-Müniriyye, ts.), 1/159.

110 Tîbî, Fütûhu'l-gayb, 2/206; Muhammed b. Alî b. Muhammed eş-Şevkânî, Fethü'l-kadîr: el-Cami' beyne fenneyi'r-rivâye ve'd-dirâse min ilmi't-tefsîr, ed. Yusuf el-Gavuş (Beyrut: Darü'l-Ma'rife, 1428), 32; Âlûsî, Rûhu'l-me'ânî, 1/159.

111 Tîbî, Fütûhu'l-gayb, 2/206; Şevkânî, Fethü'l-kadîr, 32.

112 Âlûsî, Rûhu'l-me'ânî, 1/159.

113 Ebû Abdillâh Muhammed b. Muhammed b. Muhammed b. Arafe el-Vergammî İbn Arafe, Tefsîru Íbn 'Arafe, thk. Celâl Esyûtî (Beyrut: Darü'l-Kütübi'l-i̇lmiyye, 2008), 1/57. 
sanki olmuş bitmiş manasındadır. ${ }^{114} \mathrm{Bu}$, muzâri sigada olmayan bir manadır. ${ }^{115}$ Allah ile melekler arasındaki bu konuşmanın istişarenin önemine işaret ettiği tespitine katılmıyoruz. Zira ism-i fâildeki kesinlik ve muhatabına "bu işi olmuş bitmiş bil" manası böyle bir çıkarıma engeldir.

\section{3. Örnek: Âl-i İmrân, $3 / 134$}

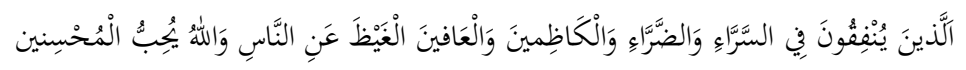

Ayette öfkeyi tutmak ve affetmek ifadeleri için isim, infak için fiil sigası kullanılmıştır. Zira öfkeyi tutma (وَالْخَاظِمِينَ) ve affetme ( وَالْعَافينَ ) eylemlerinde devamlılık ${ }^{116}$ vardır. İnfak ise "teceddüt" eder, yani ihtiyaç hâsıl olduğunda verilir. Bunun için fiil kullanılmıştır.117 İnfak ile ilgili benzer kullanımı Kur’an-ı Kerim’de başka ayetlerde de görmekteyiz. Mesela Bakara Sûresi 274,118 Âl-i İmrân Sûresi 134119 ve Nisâ Sûresinin 38.120 ayetlerinde fiil sigası kullanılmıştır. İlgili ayetlerde hep muzâri fiil kullanılması, infakın tekrar eden, sürekli olan özelliği sebebiyledir. Bunun tek istisnası Âl-i İmrân Sûresinin 17. ayetidir. ${ }^{121}$ Burada isim sigasının kullanılması ise ayette genel olarak müminlerde sabit olan vasıfların zikredilmesi sebebiyledir. ${ }^{122}$

\section{4. Örnek: el-Mâide, $5 / 28$}

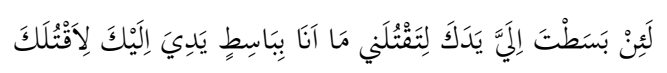

Ayette Kâbil'in eylemi ile ilgili fiil kullanılırken Hâbil'inki ile ilgili isim kullanılmıștır. İsim kullanılması Hâbil'in adeta ben böyle birisi değilim; bu vasıf ve karakterde birisi değilim demiş olduğuna işarettir. ${ }^{123}$ Eğer burada fiille cevap verilseydi, 'ben şu an elimi uzatmam ya da gelecekte elimi uzatmayacağım' manasına

114 Muhammed b. Yusuf Ebû Hayyân el-Endülisî Ebû Hayyân, Tefsîrü'l- bahri'l-muhît, ed. Âdil Ahmed Abdülmevcûd - Alî Muhammed Muavvez (Beyrut: Darü'l-Kütübi'l-İlmiyye, ts.), 1/287; Sâmerraî, et-Ta'biru'l-Kur'anî, 22.

115 Muhammed el- İmâdî Ebûssuûd, Tefsîrü Ebî's-su 'ûd: İrşâdü akli's-selîm ilâ mezâyâ'l-Kitabi'l-Kerîm, thk. Abdulkadir Ahmed Âtâ (Riyad: Mektebetü'r-Riyâd el-Hadîse, ts.), 1/14.

116 Razi burada istimrar (استمرار) kelimesini kullanmıştır. Fakat fiil için kullanılan istimrarı burada devam (دوام) ile eş anlamlı kullanmıştır.

117 Ebûssuûd, Tefsîrü Ebî's-su'ûd, 1/556.

118 “Mallarını gece be gündüz gizli ve aşikar infak edenlerin ecirleri Rableri katındadır. Onlara korku yoktur, onlar hüzünlenmeyeceklerdir de." "Bollukta darllkta infak edenler, öfkelerine hakim olanlar, insanların kusurlarını görmezden gelenler Allah Muhsin kimseleri sever. “

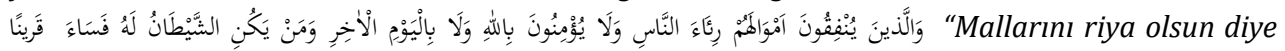
verenler, bu kimseler ahiret gününe de inanmazlar şeytan kime arkadaş olduysa o ne kötü arkadaștır."

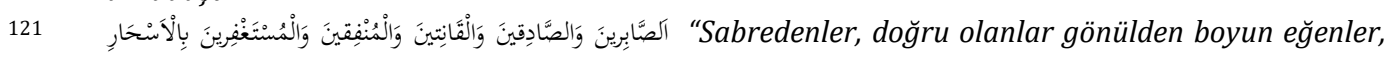
infakta bulunanlar ve seher vakti istiğfarda bulunanlar."

122 Sâmerraî, et-Ta'biru'l-Kur'anî, 29,30.

123 Zemahșerî, el-Keşşấf, 1/613; Ebû Hayyân, el- bahrü'l-muhît, 3/477; Râzî, Tefsîrü'l-fahri'r-Râzî, 11/212; Sâmerraî, Meâni'l-ebniye, 12,13. 
gelirdi. Fakat kastedilmek istenen bu değildir. 'Ben böyle biri değilim, bu vasıflarda biri değilim' manası verilebilmesi için fiil yerine isim tercih edilmiştir. Hâbil'in cevabının ism-i fâil sigası ile ifade edilmesi, sadece şu an ya da gelecekte değil, hiç bir vakit ben bu işi yapmam manası vermektedir. $\mathrm{Bu}$, fiil ile nefiyden daha beliğdir; çünkü burada herhangi bir zaman dilimi gözetilmemiştir.124

\section{5. Örnek: el-A'râf, $7 / 193$}

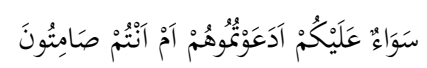

Ayet-i kerimede davet etme/çağırma yani konuşma ile ilgili fiil sigası, susma

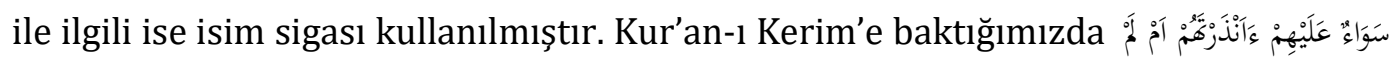
ö örneğinde ${ }^{125}$ olduğu gibi tesviye hemzesinden öncesi fiil ise sonrasında da fiil geldiğini görmekteyiz. Bu ayette fiil değil, ism-i fâil gelmiştir. Bunun sebebi sadedinde şunları zikredebiliriz. Araplar putlara sadece başları sıkıştığında sığınırlardı. Diğer zamanlardaki daimî halleri ise dua etmeyip/putlardan bir şey talep etmeyip suskun kalmaktı. Bu sebeple onlara, "putlardan bir şey isteseniz de suskun kalsanız da aynıdır, aralarında fark yoktur denmektedir. Zira bu cansız varlıkların size fayda veya zarar verme durumları yoktur. ${ }^{126}$ Onların putlara sadece başları sıkıştığında müracaat ettiklerini ifade için teceddüt anlamı içeren fiil kullanılırken, genel halleri olan suskunluk için ise sebat manası taşıyan ism-i fâil kullanılmıştır. Önceki satırlarda belirtildiği gibi isim sigasının kullanılması daha vurgulu bir ifade biçimidir. Müşriklerin genel hali olan suskunluğu ortaya koymada bağlama daha uygun düşmüştür. ${ }^{127}$ Ayrıca eğer suskunluklarına fiil sigasıyla işaret edilseydi, sadece mazi manası verirdi. Bu sebeple hem maziye hem de hale delalet etmesi için isim sigasında gelmiştir. ${ }^{128}$ Nesefî (öl.710/1310), burada fiil değil de isim sigasının kullanılmasının fasıladan dolayı olduğunu söylemiştir. ${ }^{129}$ Hatta Sîbeveyhi'nin (öl. 180/796) de ile صَمَمْمَم arasında fark görmediği aktarılsa da ${ }^{130}$ modern dönem müfessirlerinden İbn Âşûr'un gayet isabetli bir biçimde belirttiği gibi durum böyle değildir. ${ }^{131}$ Zira buradaki

124 Muhammed b. Muslihiddin Mustafa el-Kûcevî el-Hanefî Şeyhzâde - Muhammed Abdulkadir Şahin, Hâşiyetü Muhyiddin Şeyhzâde alâ tefsirî̀l-Kâdî Beyzâvî (Beyrut: Darü'l-Kütübi'l-İlmiyye, 1419/1999), 3/512.

125 El-Bakara 2/6; Yâsin 36/10.

126 Râzî, Tefsîrü'l-fahri'r-Râzî, 15/96; Ebû Hayyân, el- bahrü'l-muhît, 4/439; Muhammed Mütevellî Şa'râvî, Tefsirü'ş-Şa'râvî, ts., 4522.

127 Ebü’l-Kāsım Muhammed b. Ahmed b. el-Kelbî İbn Cüzey, et-Teshîl li-ulûmi't-Tenzîl, ed. Muhammed Salim Haşim (Beyrut: Darü'l-Kütübi'l-İlmiyye, 1415/1995), 2/333; Ebûssuûd, Tefsîrü Ebî̀s-Su'ûd, 2/453; Âlûsî, Rûhu'l-me ânî, 9/143.

128 Ebû Alî el-Fazl b. Hasan et-Tabersî, Mecmau'l-beyân fî tefsîri'l-Kur'an (Beyrut: Darü'l-Ulûm, 1426/2005), 4/304.

129 Ebü'l-Berekât Abdullah b. Ahmed b. Mahmud en-Nesefî, Tefsîrü'n-Nesefí: Medârikü't-Tenzîl ve hekâikü't-te'vîl, ed. Yusuf Ali Bedevî (Beyrut: Darü'l-Kelimi't-Tayyib, 1419/1998), 1/625.

130 Ebû Abdullah Muhammed b. Ahmed b. Ebî Bekr el-Kurtubî, el-Cami'u li-ahkâmi'l-Kur'an ve'l mübeyyinü limâ tezammanehü mine's-sünne ve âyi'l-furkân, thk. Abdullah b. Abdülmuhsin et-Türkî (Beyrut: Müessesetü'r- Risâle, 1427/2006), 9/415.

131 İbn Âșûr, Tefsîrü't-tahrîr ve't-tenvîr, 9/220. 
isim ile fiil kullanımı arasındaki fark açıktır. Eğer iddia edildiği gibi isim sigası tercihi fasıladan kaynaklansaydı aynı uyumu sağlayacak olan تصمتون de denebilirdi. 132

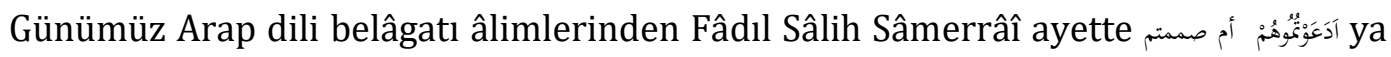

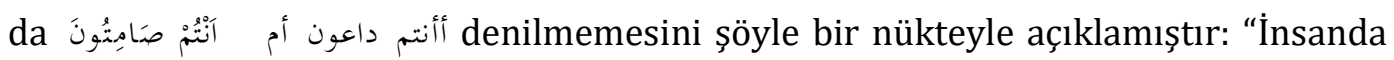
kalıcı olan vasıf susmaktır. Ancak bir sebebe istinaden konuşur, durduk yere konuşmaz. Bundan dolayı ayette böyle bir ayrıma gidilmiş; susma hali için isim sigası, konuşma için fiil sigası kullanılmıştır."133

\section{6. Örnek: el-Enfâl, $8 / 33$}

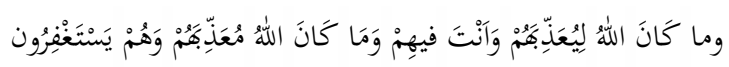

Ayette azap edilmesiyle ilgili birincisinde fiil, ikincisinde isim kullanılmıştır. Ayet-i kerimede azabın gelmemesi iki duruma bağlanmıştır. Birisi peygamberin aralarında olması, diğeri ise istiğfar edilmesi. Ayette azap edilmemenin istiğfara bağlı olmasıyla ilgili olarak isim sigası kullanılmıştır. Bu, istiğfarın daha kalıcı olduğunu gösterir. Peygamberin aralarında olması ise geçicidir; zira bir süre sonra vefat edip ayrılacaktır. Bu ayrılığa, geçiciliğe işaret olsun diye peygamberin aralarında olması sebebiyle azaba uğramayacakları ise fiil sigası ile ifade edilmiştir.134 Benzer bir

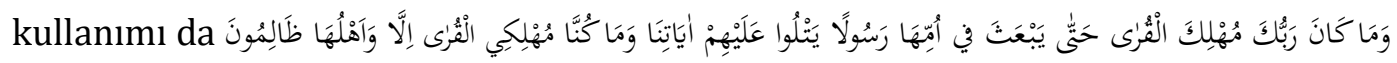
el-Kasas 29. ayetinde de görmekteyiz. Toplumların helak olması zulmün onlarda sabit bir vasıf olması sebebiyledir. Bu sebeple sebata delalet eden isim sigası kullanılmıştır ( وَاهَلْهَا ظَالِمِوُنَ ( ). Bu kullanımdan hareketle zulmün onlarda geçici bir özellik değil, kalıcı bir vasıf olduğu anlaşılmaktadır. Bu kötü özelliklerinden dolayı azabı hak etmişlerdir.135 İki ayeti birlikte ele aldığımızda dikkat çeken bir nükteyle karşılaşmaktayız. İstiğfar, istiğfar eden kimselerde sabit bir özellik olmasa da Allah onlardan azabı gideriyor. Azap etmeye gelince ise zulüm onlarda kalıcı özellik halinde değilse onlara azap etmiyor. Ayetlerde buna işaret olsun diye istiğfar fiil, ${ }^{136}$ zulüm ise ${ }^{137}$ ism-i fâil ile ifade edilmiştir. Bu, Allah'ın engin rahmetine delalet etmektedir. ${ }^{138}$

\section{7. Örnek: Yûsuf, 12/58}

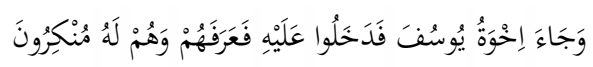

Bu ayette Yûsuf peygamberin kardeşlerini tanımasıyla ilgili fiil, kardeşlerinin onu tanımayışıyla ilgili ise ism-i fâil sigası kullanılmıştır. Kardeşlerinin Yûsuf'u tanımayışının isimle ifade edilmesi bu durumun onlarda sabit, kalıcı olduğunu

\footnotetext{
132 Âlûsî, Rûhu'l-me'ânî, 9/143.

133 Sâmerraî, Meâni'l-ebniye, 11.

134 Sâmerraî, el-Cümletü'l-'Arabiyye, 163; Sâmerraî, et-Ta'biru'l-Kur'anî, 26.

135 Sâmerraî, et-Ta'biru'l-Kur'anî, 26.

136 Enfal suresi 33. ayetteki وَهْمْ يَسْنَغْفْرُونَ ifadesi.

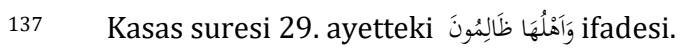

138 Sâmerraî, et-Ta'biru'l-Kur'anî, 26.
} 
göstermektedir. Yûsuf peygamberin onları tanıdığının fiille ifade edilmesinde ise onları ilk gördüğünde düşünmeden, onları incelemeden tanıdığına bir işaret vardır. ${ }^{139}$ Onlar Yûsuf peygamberi tanıyamamıştır; zira aradan uzun zaman geçmiş, Yûsuf peygamber fiziki olarak çok değişmiş, kral elbiseleri giymişti. Onlar ise bu durumu akıllarına bile getiremiyordu; zira Yûsuf'u çok uzun süre terk etmişler ve bu hadiseyi de unutmak istiyorlardı. Bu sebepten tanıyamamışlardır. Yoksa tanıyıp tanımama noktasında Yûsuf peygamberle aynı konumda değillerdi. ${ }^{140}$

\section{8. Örnek: en-Nahl, $16 / 96$}

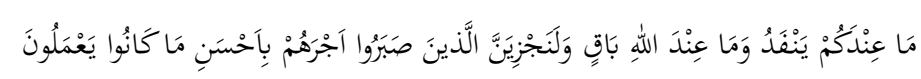

Ayette 'bitmek tükenmek' fiil, 'kalmak' ise isim sigasıyla kullanılmıştır. Zira tükenmek değişimdir, yok olmaktır; kalma ise sabit olma, daim olmadır. Bu sebeple değişimle, yok olmakla ilgili fiil sigası; kalma, sabit olma ile ilgili ise isim sigası kullanılmıștır. ${ }^{141}$

\section{9. Örnek: el-Ankebût, $29 / 3$}

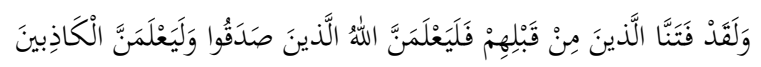

Doğruluklarını ortaya koyanlar/izhar edenler için fiil sigası, yalanda sürekli olanlar için ise isim sigası kullanılmıştır. ${ }^{142}$ Onlar bu vasıfla bilinip ayırt edildikleri için isim sigası kullanılmıştır. ${ }^{143}$ Zira ayet-i kerime yeni Müslüman olanlardan bahsediyordu, bu kimseler daha İslami teklifin ilk başlarındaydı, aşamasındaydı. Bahsettiği kâfirler ise öteden beri küfür üzere olan, küfürde ısrar edenlerdi. Dolayısıyla müminler hakkında, onlardan doğruluk sadır oldu, doğruluk bulundu (ortaya çıktı) manasında fiil sigası; kâfirler hakkında ise küfür üzere sebat ettikleri, küfürlerinde daimi oldukları için isim sigası kullanılmıştır. ${ }^{144}$ Mâide Sûresinin 119. ayetindeki145 ism-i fâil lafzının kullanımı da bu görüşü desteklemektedir. Zira o günde doğruluk müminin kalbine yerleşmiştir, 0 gün son gündür, İslam'ın başlangıcı değildir. ${ }^{146}$

\section{Sonuç}

İsim ile fiil arasındaki belirgin farklardan birisi de ismin zamanla ilgisinin olmamasıdır. Bu tespit bazen ism-i fâilin mazi ve hal manalı işleviyle çelişir gibi

\footnotetext{
139 İbn Âșûr, Tefsîrü't-tahrîr ve't-tenvîr, 13/12.

140 Ebûssuûd, Tefsîrü Ebî's-Su'ûd, 3/162.

141 İbn Arafe, Tefsîru İbn 'Arafe, 46; Ebûssuûd, Tefsîrü Ebî's-Su'ûd, 3/397.

142 Ebûssuûd, Tefsîrü Ebî's-Su'ûd, 4/325.

143 İbn Âşûr, Tefsîrü't-tahrîr ve't-tenvîr, 20/206.

144 Râzî, Tefsîrü'l-fahri'r-Râzî, 25/30; Şeyhzâde - Muhammed Abdulkadir Şahin, Hâșiyetü Şeyhzâde, 6/485; Mahmud es-Safî, el-Cedvel fí i'râbi'l- Kur'an ve sarfihi ve beyanihi mea fevâide nahviyye belâgiyye (Dımeșk-Beyrut, 1416/1995), 10/309.

$145 \quad$ يوم ينفع الصادقين صدقهم

146 Râzî, Tefsîrü'l-fahri'r-Râzî, 25/30.
} 
durmaktadır. Bununla beraber ismin zamana delaleti mümkündür; fakat bu, karineyle olur, fiildeki gibi kendiliğinden olmaz kaydının dikkate alınması gerekmektedir.

"Fiil teceddüt ifade eder" genel tespitinin mazi fiille kullanımı düşünüldüğünde kafalarda soru işareti oluşuyordu. Zira teceddüdün manası yenilenmektir, mazi siga ise geçmişte gerçekleşen bir eylem için söz konusudur. "Teceddüt" mazi ile kullanıldığında sadece, önceden ortada yokken sonradan ortaya çıkma manasıyla ilgili olduğu neticesine varılmıştır. Yani teceddüdün ilk manası dikkate alınır, ikinci mana, fiilin kesik kesik meydana gelmesi sadece muzâri siga ile ilgilidir.

"Sübût" ya da "hudûs" ifade eden isim cümlesi ya da fiil cümlesi değil, cümlede bulunan isim veya fiilin bizzat kendisi olduğu tespit edilmiştir.

"Devam" ile "sübût" kavramlarının tamamen aynı anlama gelmedikleri anlaşılmıştır. "Devam" belli bir zaman dilimiyle kayıtlanmanın, "sübût" ise "teceddüt" ün mukabilidir. Aralarındaki bir diğer fark ismin "sübût”a delaletinin vaz'ı itibariyle oluşu; fakat "devam"a delaletinin ise bir karineyle gerçekleşmesidir. Bu karine ya medh, ya da zemm ile olur. Aralarındaki ilişki bir başka açıdan şöyle de formülize edilebilir: Bir şeyin devamlı oluşu onda aynı zamanda "sübût" olduğu anlamına gelir. Fakat "sübût" olan aynı zamanda "devam" da ifade eder denilemez.

"Devam" ile "istimrâr" kavramlarının aynı anlamda kullanıldığını, kullanılabileceği sonucuna ulaşılmıştır. Aralarındaki farkın "devam"ın isim ile, "istimrârın" ise fiil ile ilgili kullanılmasıdır. Bir diğer fark fiilin "istimrâr"a işareti yenilenen zamanı ihtiva etmesi sebebiyle, ismin devam ifade etmesi ise makam iledir; yani medh ya da zem manası gözetildiğindedir.

Kur'an-ı Kerim'in ism-i fâil ve fiil tercihlerinin sadece tefennünle ifade edilemeyeceği neticesi elde edilmiştir. Zira yer yer her ikisi de aynı anlamda kullanılmış intibaı verse de dikkatle incelendiğinde bir nükteye işaret ettiği görülecektir.

Arap dilindeki bu kullanım farklılıklarının değişik ilmi disiplinler özellikle de fıkıh, kelâm ahlâk, sosyoloji ve psikoloji için vazgeçilmez öneme sahip olduğu anlaşılmıștır. İlahiyat fakültelerindeki Arap Dili ve Belâgatı anabilim dalının temel İslam bilimleri başta olmak üzere değişik ilmi disiplinlere bu konularda daha çok katkı sunması gerektiği kanaati hâsıl olmuştur. 


\section{Kaynakça}

Abbas Hasan. en-Nahvü'l-vafî. Tahran: Avand Danîș, 1. Basım, 1425/2004.

Âlûsî, Ebû'l-fazl Şihâbüddîn es-Seyyid Mahmud. Rûhu'l-me'ânî fî tefsîri'l-Kur'ani'l- 'Azîm ve Seb 'i'l-Mesânî. 30 Cilt. Beyrut: İdâretü't-Tıbâati'l-Müniriyye, ts.

Bamyânî, Muhammedî. Durûs fíl-belâga. 4 Cilt. Müessesetü'l-Belâg, 1. Basım, 1429/2008.

Cevherî, Ebû Nasr İsmâil b. Hammâd. es-Sıhâh: Tacü'l-lüga ve sıhâhü'l-'Arabiyye. thk. Ahmed Abdülgâfur Attâr. 6 Cilt. Beyrut: Darü'l-İlmi lil-Melayîn, 4. Basım, 1990.

Cürcânî, Abdülkâhir. Delâilü'l-i'câz fî ilmi'l-me'ânî. thk. Seyyid Muhammed Reșit Rızâ. Beyrut: Darü'l-Ma'rife, 3. Basım, 1422/2001.

Cürcânî, Abdülkâhir. Delâilü'l-i'câz: Sözdizimi ve Anlambilim. çev. Osman Güman. İstanbul: Türkiye Yazma Eserler Kurumu Başkanlığı, 1. Basım, 2015.

Çifçi, M. Faruk. "Kemalpaşazâde'ye Göre Müşâkele Sanatı (Problemler ve Eleştiriler)”, Hitit Üniversitesi İlahiyat Fakültesi Dergisi 9 (2020), 119-150.

Desûkî, Muhammed Ahmed b. Arafe. Hâşiyetü't-Desûkî ala muhtasarı's-Sa'd. thk. Halil İbrahim Halil. 4 Cilt. Beyrut: Dârü'l-Kütübi'l-İlmiyye, 2. Basım, ts.

Duran, Hasan - İnanç, Yunus. “Kur’ân-ı Kerîm’de Teceddüt ve Sübût Manası İçin Yapılan 'Udûl Çeşitleri”. Edebali İslamiyat Dergisi 3/5 (Mayıs 2019), 53-77.

Ebû Hayyân, Muhammed b. Yusuf Ebû Hayyân el-Endülisî. Tefsîrü'l- bahri'l-muhît. ed. Âdil Ahmed Abdülmevcûd - Alî Muhammed Muavvez. 8 Cilt. Beyrut: Darü'l-Kütübi'lİlmiyye, 1. Basım, ts.

Ebûssuûd, Muhammed el-'iâdî. Tefsîrü Ebî's-Su'ûd: Irșâdü akli's-selîm ilâ mezâyâ'l-Kitabi'lKerîm. thk. Abdulkadir Ahmed Âtâ. 5 Cilt. Riyad: Mektebetü'r-Riyâd el-Hadîse, ts.

Fîrûzâbâdî, Mecdüddin Muhammed b. Ya'kub. el-Kâmûsü'l-muhît. thk. Mektebetü Tahkîki'tTürâs fî Müesseseti'r-Risâle. Beyrut: Müessesetü'r- Risâle, 6. Basım, 1998.

Galâyînî, Mustafa. Camiü'd-durûsi'l-'Arabiyye. thk. Ahmed İbrahim Zehve. Beyrut: Darü'lKitabi'l-'Arabî, 2009.

Hamlâvî, Ahmed. Şeze'l-'arffî fenni's- sarf. Beyrut: el-Mektebetü'l-Asriyye, 2007.

İbn Akîl, Behâü'ddin Abdullah. Şerhu İbn Akîl alâ elfiyeti İbn Mâlik. ed. Muhammed Muhyiddin Abdulhamîd. 4 Cilt. Dımeşk: Darü'l-Fikr, 16. Basım, ts.

İbn Arafe, Ebû Abdillâh Muhammed b. Muhammed b. Muhammed b. Arafe el-Vergammî. Tefsîru İbn 'Arafe. thk. Celâl Esyûtî. 4 Cilt. Beyrut: Darü'l-Kütübi'l-İlmiyye, 1. Basım, 2008.

İbn Âșûr, Muhammed Tâhir. Tefsîrü't-tahrîr ve't-tenvîr. 30 Cilt. Tunus: ed-Dârü't-Tunisiyye, 1984.

İbn Cüzey, Ebü'l-Kāsım Muhammed b. Ahmed b. el-Kelbî. et-Teshîl li-ulûmi't-Tenzîl. ed. Muhammed Salim Haşim. 2 Cilt. Beyrut: Darü'l-Kütübi'l-İlmiyye, 1. Basım, 1415/1995.

İbn Fâris, Ebü'l-Hüseyin Ahmed b. Fâris b. Zekeriyyâ. Mu'cemü mekâyîsi'l-luga. thk. Enes Muhammed Şamî. Kâhire: Darü'l- Hadîs, 1429/2008.

İbn Hişâm, Cemâlüddin Abdülmelik b. Hişam. Şüzûrü'z-zeheb. ed. Berekât Yusuf Hebbûr. Dımeşk-Beyrut: Darü İbn Kesîr, 1434/2013.

İbn Manzûr, Ebü'l- Fazl Cemâlüddin Muhammed b. Mükerrem b. Ali b. Ahmed el Ensarî erRüveyfiî. Lisanü'l-'Arab. thk. Abdullah Ali el-Kebîr - Muhammed Ahmed Hasbillah. 6 Cilt. Kâhire: Darül-Meârif, ts.

İbn Serrâc, Ebû Bekr Muhammed b. Sehl b. Sirâc en-Nahvî el-Bağdadî. el-Usûl fî́n-nahv. 2 Cilt. Beyrut: Müessesetü'r- Risâle, 3. Basım, 1417/1996.

Kazvînî, el-Hatîb. el-Îzâh fî ulûmi'l-belâga: el-me'ânî ve'l -beyân ve'l-bedî'. Beyrut: Darü'lKütübi'l-İlmiyye, 1. Basım, 1424/2003. 
Kurtubî, Ebû Abdullah Muhammed b. Ahmed b. Ebî Bekr. el-Cami'u li-ahkâmi'l-Kur'an ve'l mübeyyinü limâ tezammanehü mine's-sünne ve âyi'l-furkân. thk. Abdullah b. Abdülmuhsin et-Türkî. 24 Cilt. Beyrut: Müessesetü'r- Risâle, 1. Basım, 1427/2006.

Mahmud Safî. el-Cedvel fî i'râbi'l- Kur'an ve sarfihi ve beyanihi mea fevâide nahviyye belâgiyye. 15 Cilt. Dımeşk-Beyrut, 3. Basım, 1416/1995.

Mecmau'l-lugati'l-Arabiyye, Mecmau'l-lugati'l-'Arabiyye. el-Mu'cemü'l-vasit. ed. İbrahim Mustafa - Ahmed Hasan Zeyyat. İstanbul: Çağrı Yayınları, 1996.

Nesefî, Ebü'l-Berekât Abdullah b. Ahmed b. Mahmud. Tefsîrü'n-Nesefí: Medârikü't-Tenzîl ve hekâikü't-te'vîl. ed. Yusuf Ali Bedevî. 3 Cilt. Beyrut: Darü'l-Kelimi't-Tayyib, 1. Basım, 1419/1998.

Râcihî, Abduh er-. et-Tatbîkü's-sarfí. Riyad: Mektebetü'l- Meârif, 1420/1999.

Râzî, Muhammed Fahrüddin Ziyâuddin Ömer. Nihayetü'l-îcâz fí dirâyeti'l-icâz. thk. Bekrî Şeyh Emin. Beyrut: Darü'l- İlmi lil-Melayîn, 1. Basım, 1985.

Râzî, Muhammed Fahrüddin Ziyâuddin Ömer. Tefsîrü'l-fahri'r-Râzî: et-Tefsîrü'l-kebîr: Mefâtîhü'l-gayb. Beyrut: Dârü'l-Fikr, 1. Basım, ts.

Sağdıç, Sedat. "Arap Dilinde İsm- Fâilin Kullanımı ve Kur'an Meallerindeki Tercüme Problemleri". Kavramlar ve Kuramlar: Dil Bilimleri. Mardin: Mardin Artuklu Üniversitesi Yayınları, 2020.

Sâmerraî, Fâdıl Sâlih. el-Cümletü'l-'Arabiyye te'lifuhâ ve aksamuhâ. Amman: Darü'l-Fikr, 2. Basım, 1427.

Sâmerraî, Fâdıl Sâlih. et-Ta'biru'l-Kur'anî. Ammân: Daru Ammâr, 4. Basım, 1427/2007.

Sâmerraî, Fâdıl Sâlih. Meâni'l-ebniye fíl-'Arabiyye. Dımeşk-Beyrut: Darü İbn Kesîr, 1. Basım, $1436 / 2015$.

Sâmerrâî, Fâdıl Sâlih. Me'ânî'n-nahv. 4 Cilt. Beyrut: Darü ihyâ, et-Türâsi'l-Arabiyyi, 1428/2007.

Şa'râvî, Muhammed Mütevellî. Tefsirü'ş-Șa'râvî, ts.

Şertûnî, Reşîd. Mebâdiü'l-Arabiyye. ed. Hâmid el-Muhammedî. 4 Cilt. Tahran: Darü'l-İlm, 17. Basım, 2011.

Şevkânî, Muhammed b. Alî b. Muhammed. Fethü'l-kadîr: el-Cami' beyne fenneyi'r-rivâye ve'ddirâse min 'ilmi't-tefsîr. ed. Yusuf el-Gavuş. Beyrut: Darü'l-Ma'rife, 1428/2007.

Şeyhzâde, Muhammed b. Muslihiddin Mustafa el-Kûcevî el-Hanefî - Muhammed Abdulkadir Şahin. Hâş̧iyetü Muhyiddin Şeyhzâde alâ tefsirî'l-Kâdî Beyzâvî. 8 Cilt. Beyrut: Darü'lKütübi'l-İlmiyye, 1. Basım, 1419/1999.

Tabersî, Ebû Alî el-Fazl b. Hasan. Mecma 'u'l-beyân fî tefsîri'l-Kur'an. 10 Cilt. Beyrut: Darü'lUlûm, 1. Basım, 1426/2005.

Teftâzânî, Sa'düddin. Muhtasarü's-Sa'd: Şerhü Telhisi Kitabi Miftahi'l-Ulûm. thk. Abdulhamid Handavî. Beyrut: el-Mektebetü'l-Asriyye, 1431/2010.

Tîbî, Şerefüddin el-Huseyn b. Abdillah. Fütûhu'l-gayb fi'l-keșf an kınâi'r-reyb. 17 Cilt. Ebû Dabî: Caizetü Dübey ed-Devliyye li'l Kur'ani'l-Kerim, 1. Basım, 1434/2013.

Yekeler, Muhammet, Câhiliye Döneminden Hz. Peygamber Dönemi Sonuna Kadar Temîm Kabilesi. İstanbul: İstanbul Üniversitesi, Sosyal Bilimler Enstitüsü, Yüksek Lisans Tezi, 2014.

Zebîdî, Muhammed Murtazâ Huseynî. Tâcü'l-arûs min cevahiri'l-kamûs. 40 Cilt. Kuveyt: Matbaatü hukumeti'l-Kuveyt, 1385/1965.

Zemahşerî, Ebûl'l-Kâsım Cârullah Mahmud b. Ömer b. Muhammed. el-Keşşâf an hakâiki gavamizi't-Tenzîl ve uyûni'l-ekâvîl fî vücûhi't-te'vil. ed. Muhammed Abdüsselam Şâhîn. 4 Cilt. Beyrut: Darü'l-Kütübi'l-İlmiyye, 1. Basım, 1995. 
Zerkeşî, Bedrüddin Muhammed b. Abdullah. el-Burhân fî Ulûmi'l-Kur'an. thk. Ebû'l-Fadl Dimyatî. Kâhire: Darü'l-Hadîs, 1427/2006. 